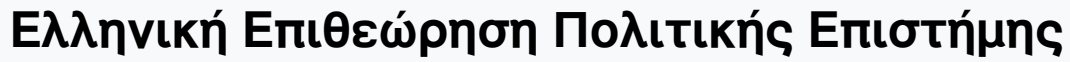

Tó 40 (2013)

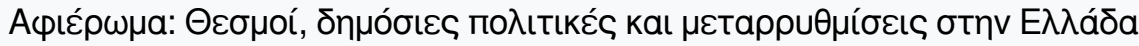

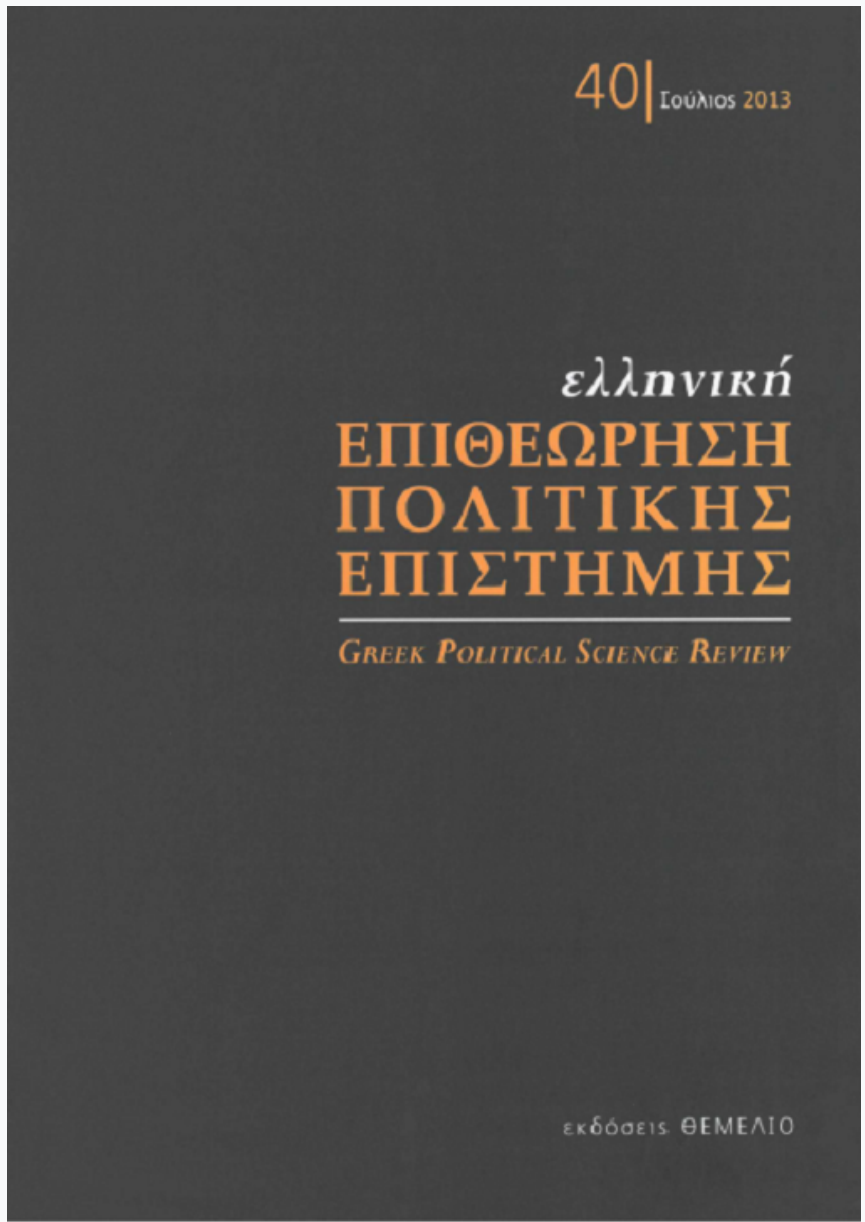

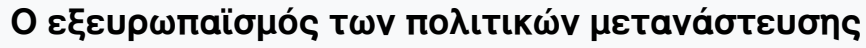

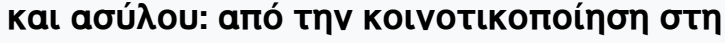

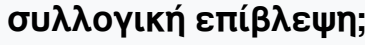

I

doi: $10.12681 / \mathrm{hpsa} .14559$

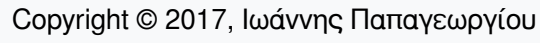

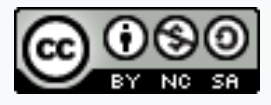

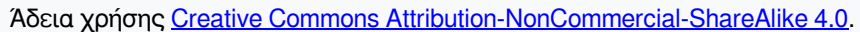

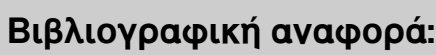

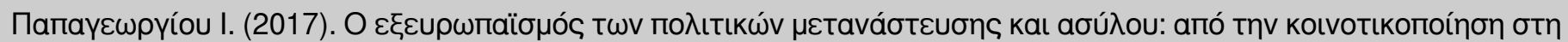

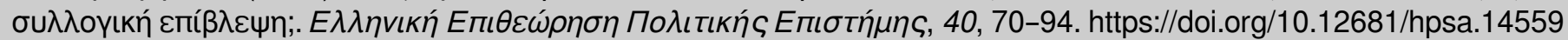




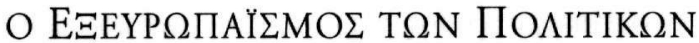 METANA AПO THN KOINOTIKOПOIH $\Sigma \mathrm{H}$

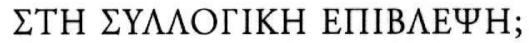

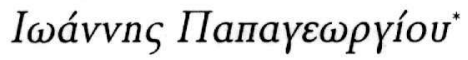

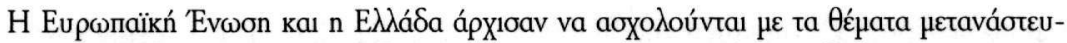

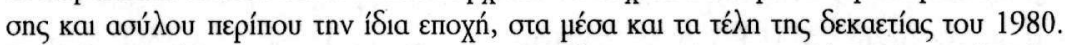

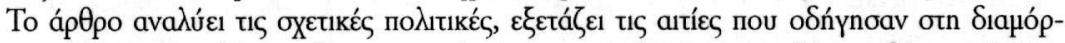

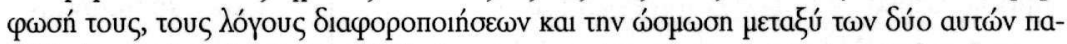

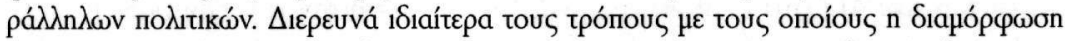

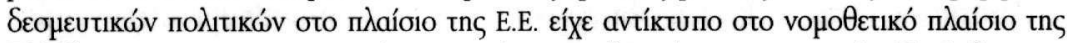

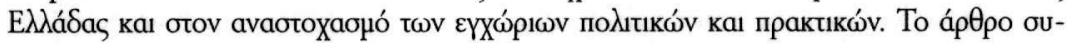

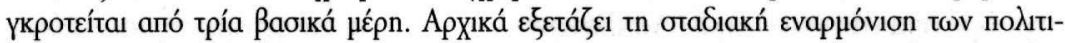

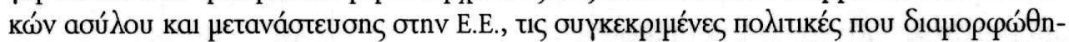

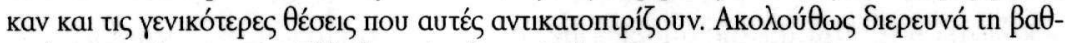

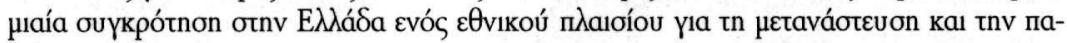

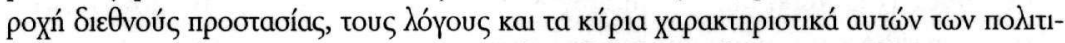

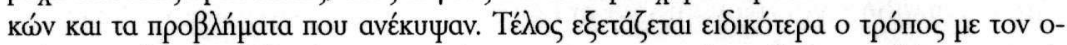

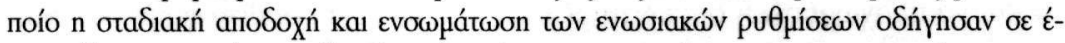

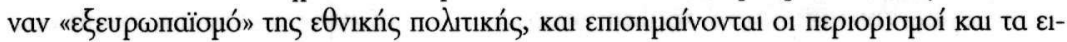

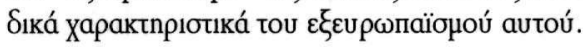

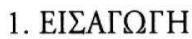

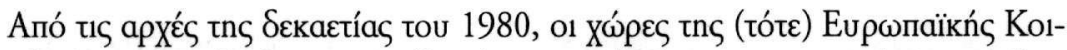

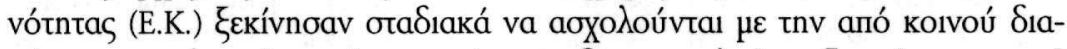

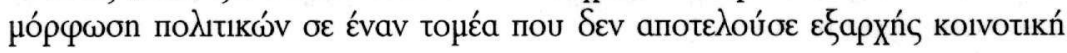

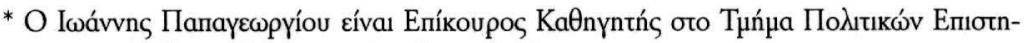

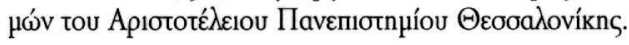




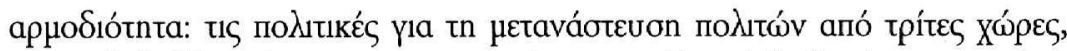

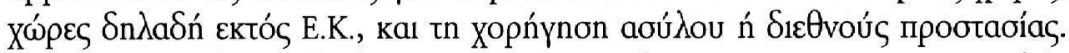

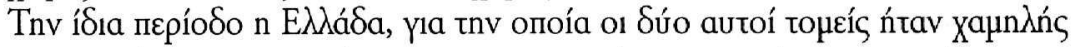

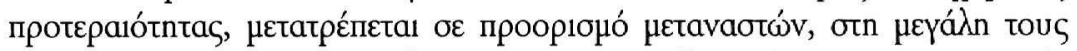

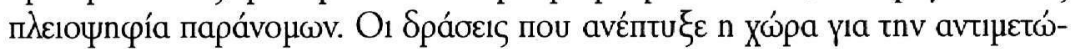

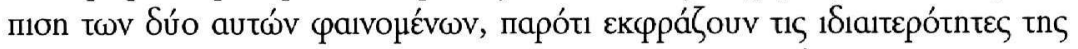

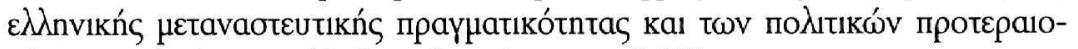

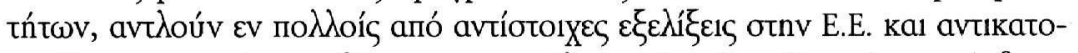

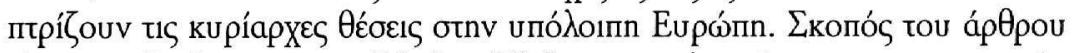

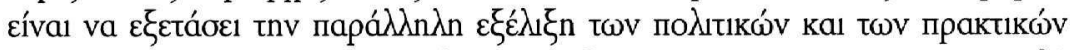

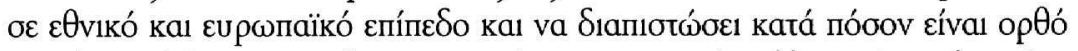

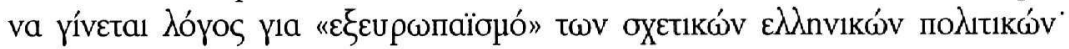

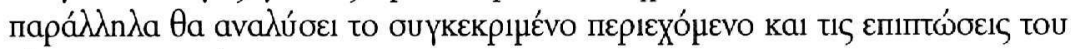

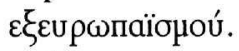

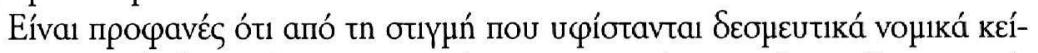

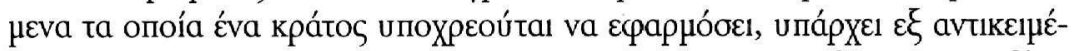

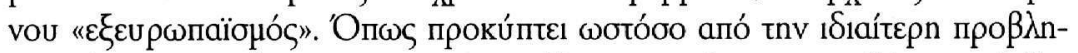

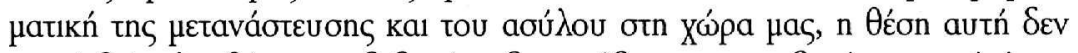

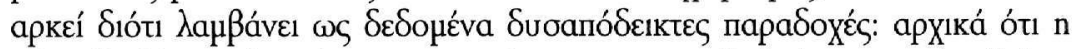
X

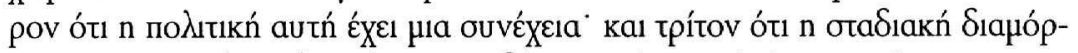

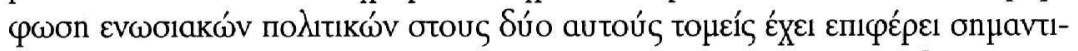

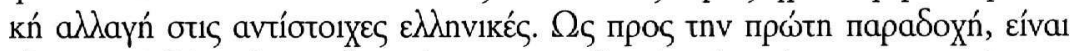

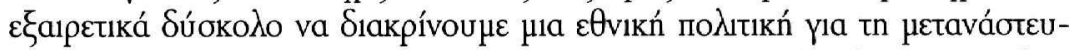

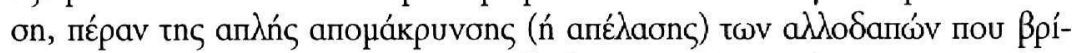

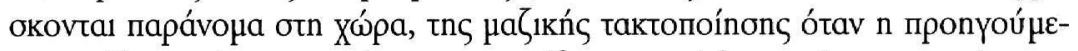

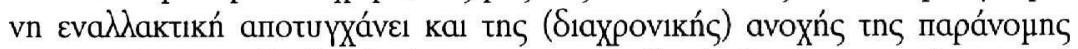

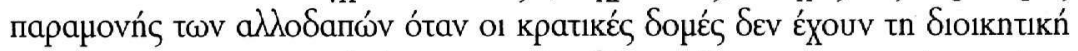

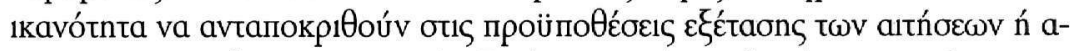

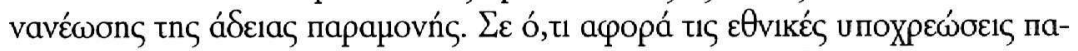

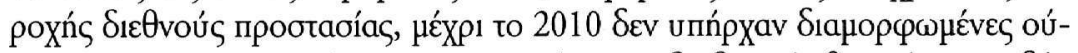

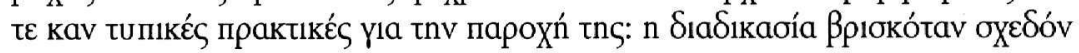

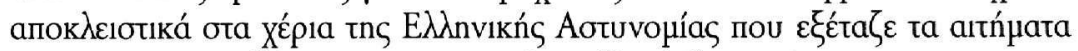

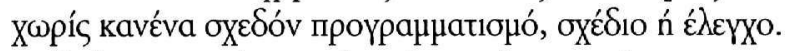

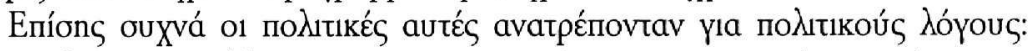

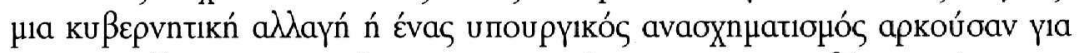

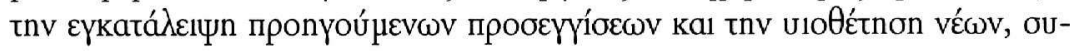




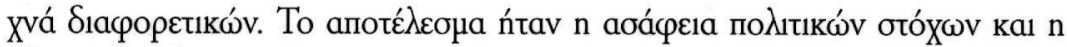

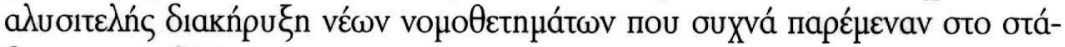

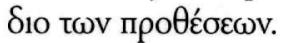

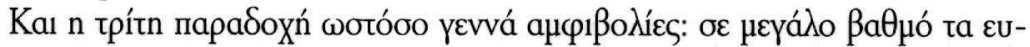

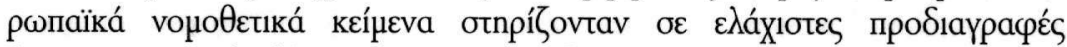

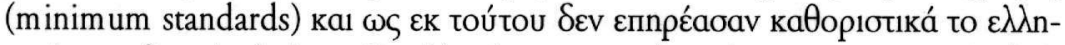

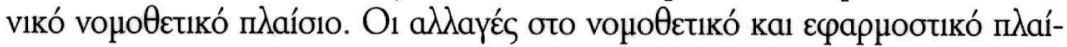

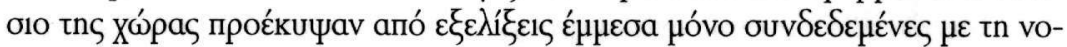

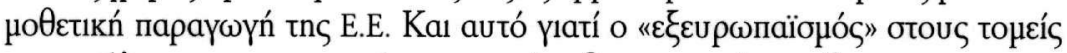

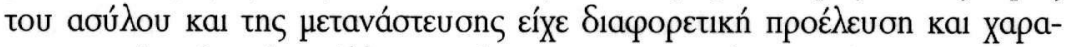

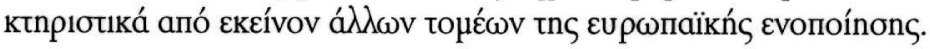

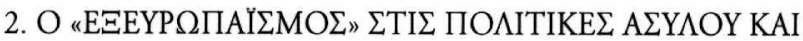

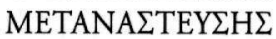

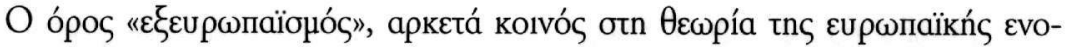

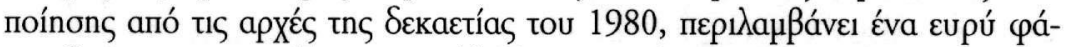

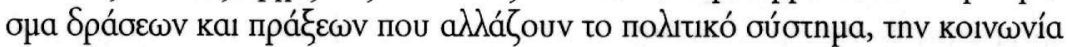

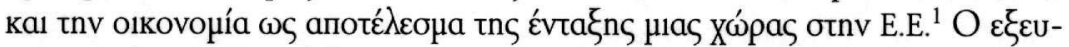

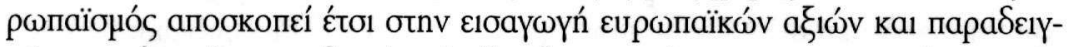

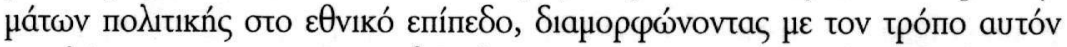

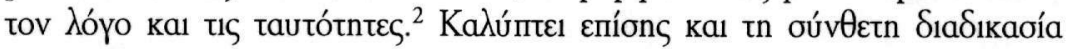

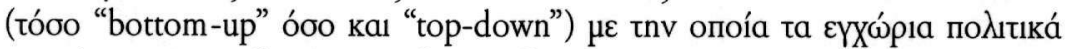

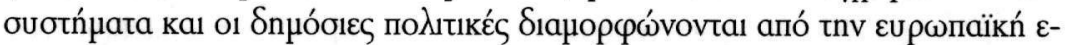

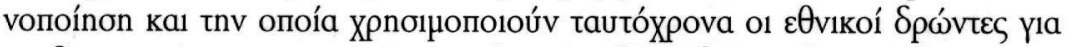

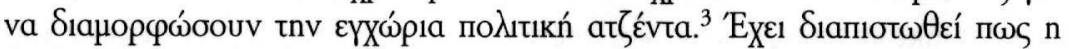

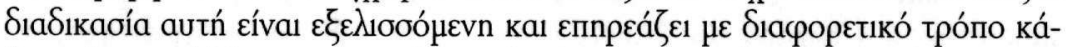

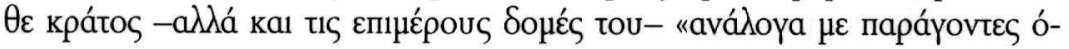

1. B $\lambda$. P.C. Ioakimidis, "The Europeanization of Greece: an overall assessment», South

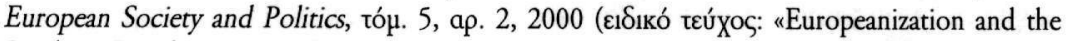

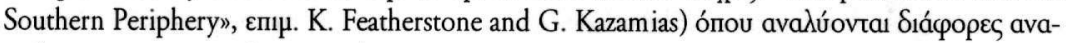

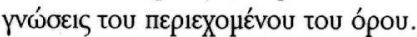

2. J.P. Olsen, "The Many Faces of Europeanization", Journal of Common Market Studies, тóp. 40, ap. 5, 2002, б. 934.

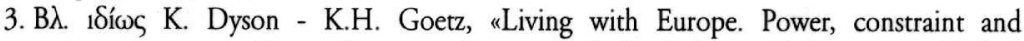

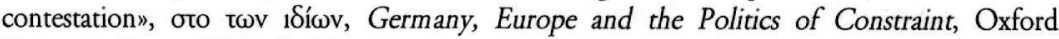

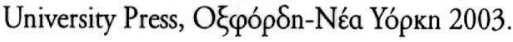




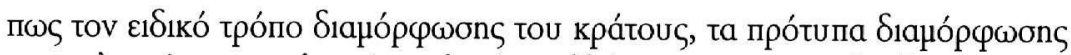

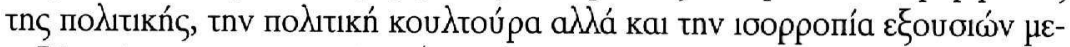

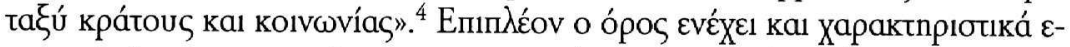

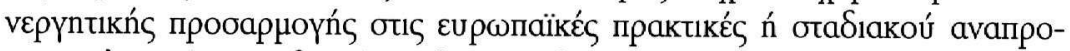

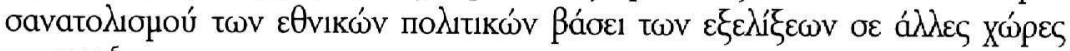
tnc E.E. ${ }^{5}$

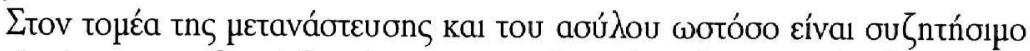

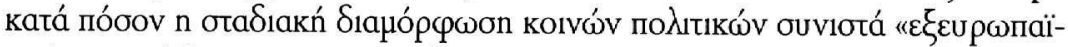

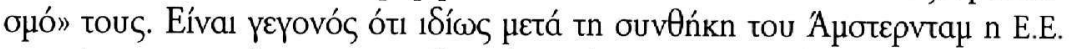

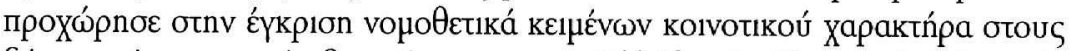

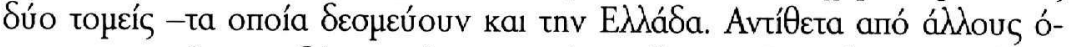

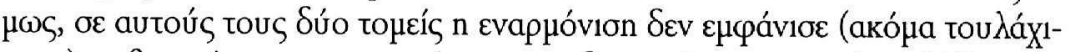

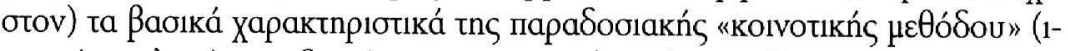

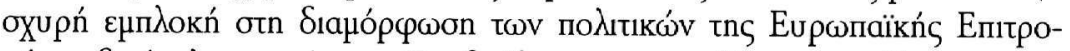

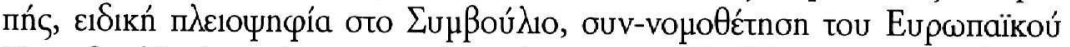

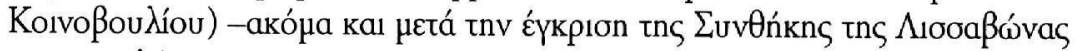

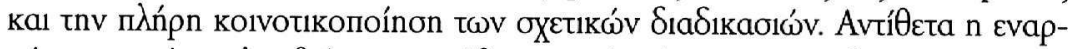

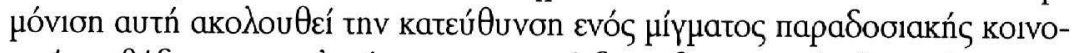

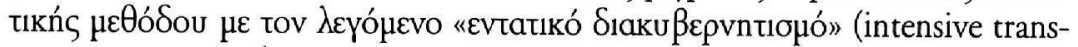

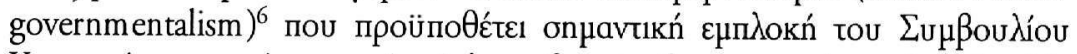

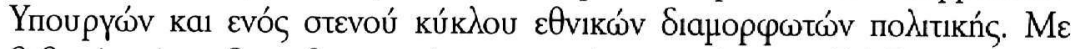

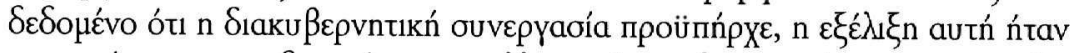

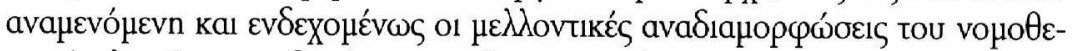

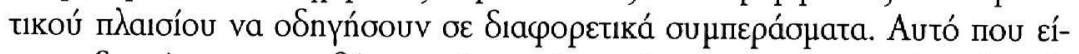

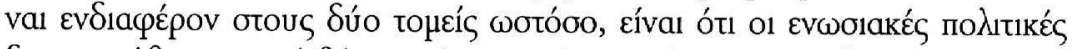

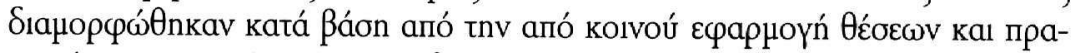

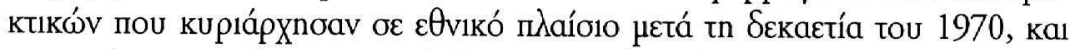
a

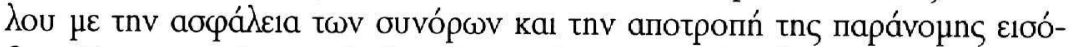

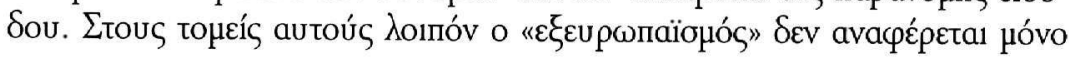

4. P.C. Ioakimidis, «The Europeanization of Greece: an overall assessment», ó.m., o. 73.

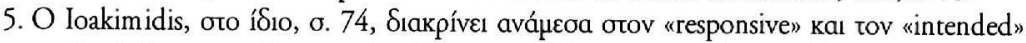

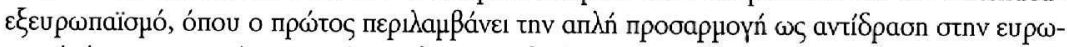

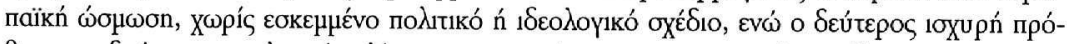

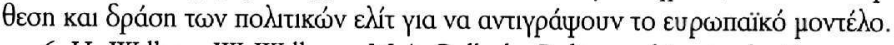

6. H. Wallace -W. Wallace - M.A. Pollack, Policy making in the European Union, 5th ed.

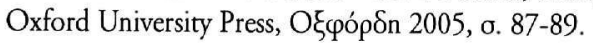




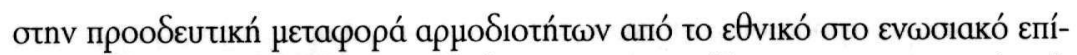

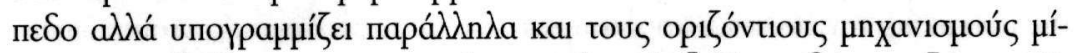

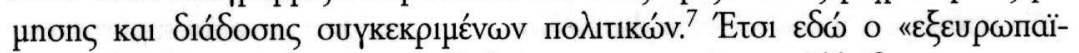

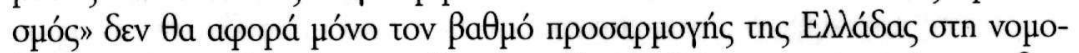

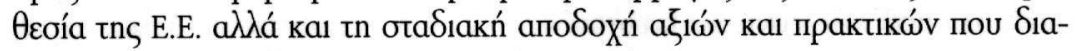

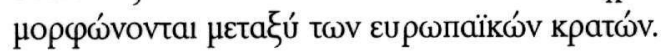

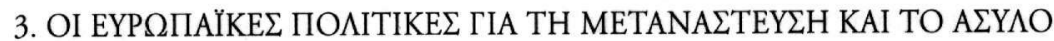

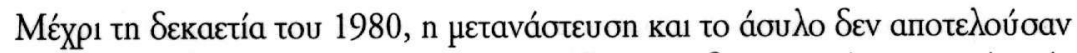

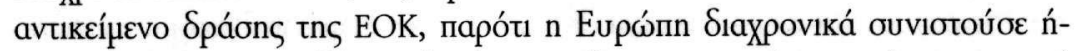

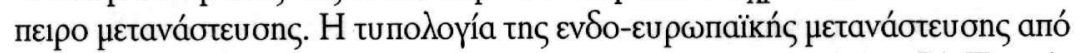

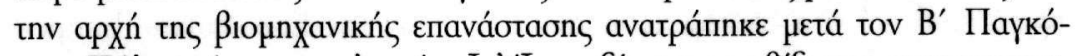

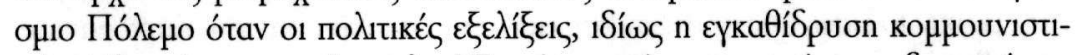

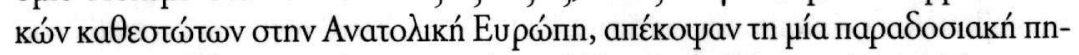

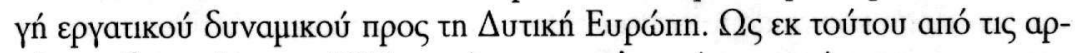

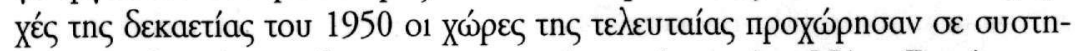

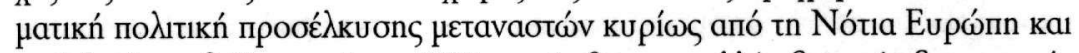

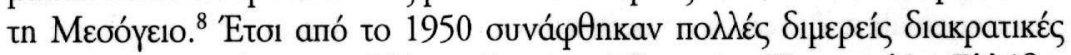

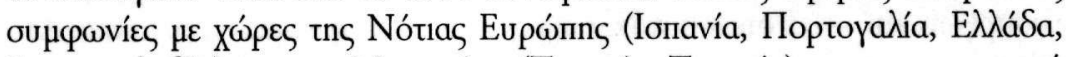

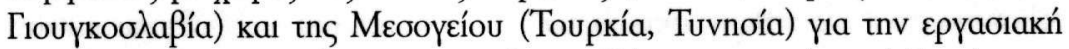

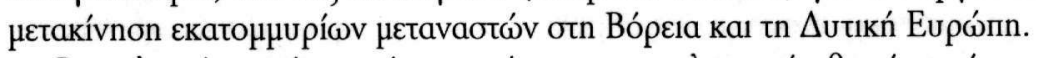

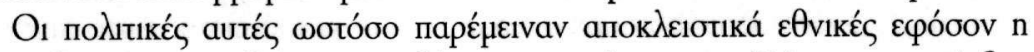

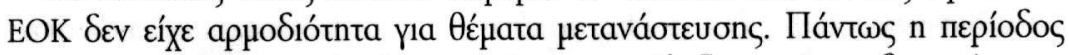

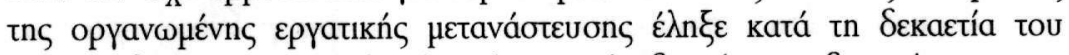

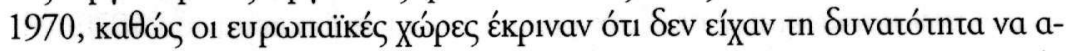

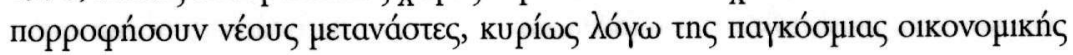

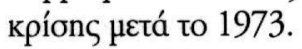

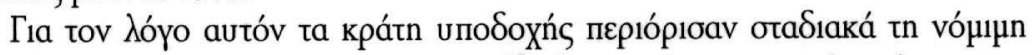

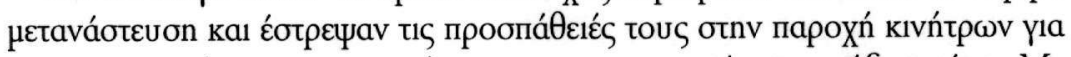

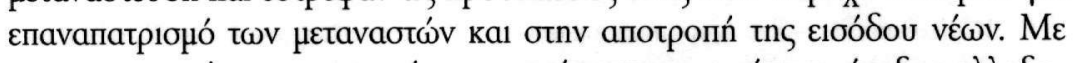

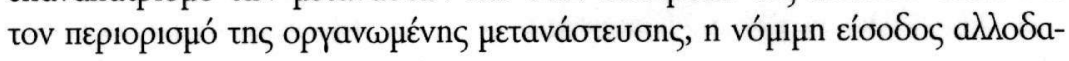

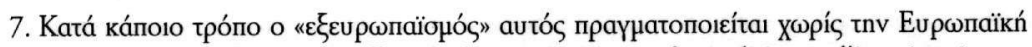
Ev $\omega \sigma n$. $B \lambda$ V. Guiraudon, «Les effets de l'européanisation des politiques d'immigration et d'asile", Politique européenne, ap. 31, 2010/2, ๙. 20.

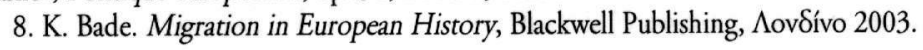




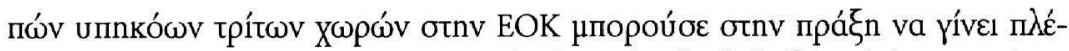

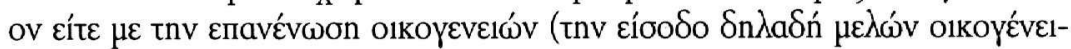

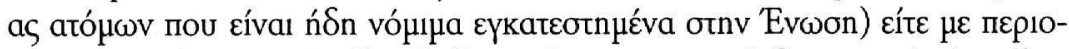

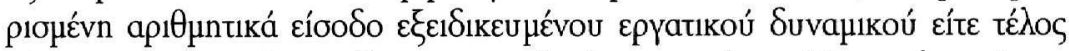

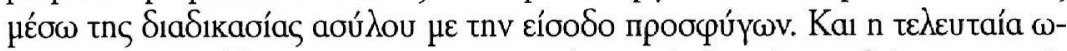

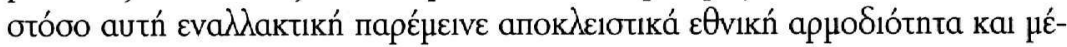

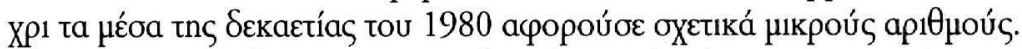

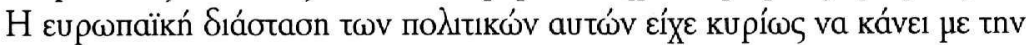

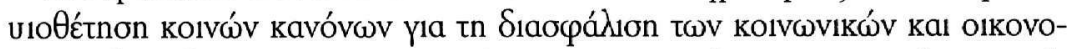

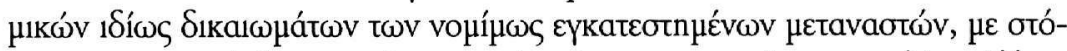

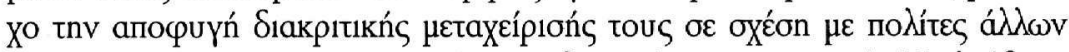

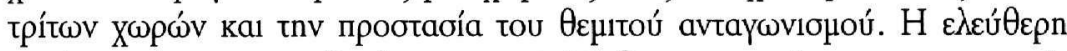

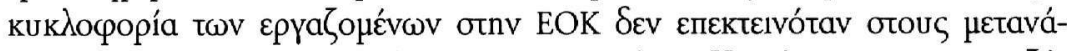

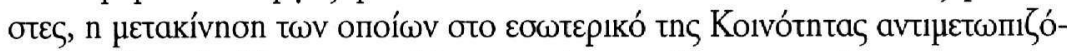

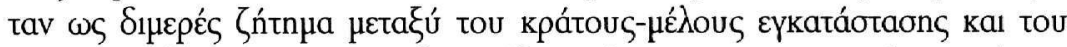

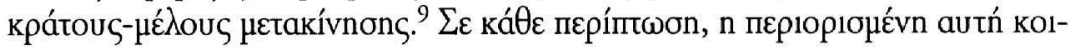

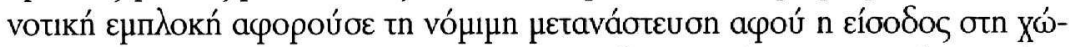

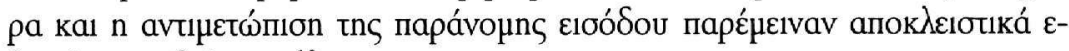

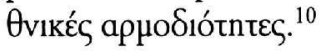

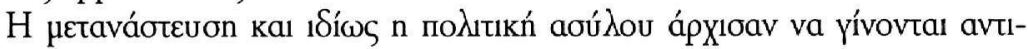

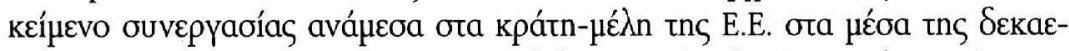

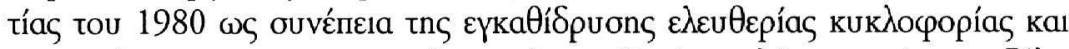

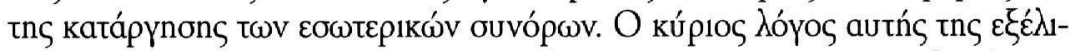

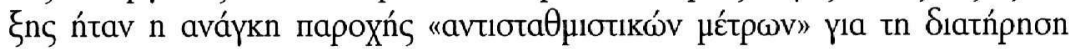

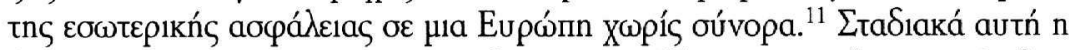

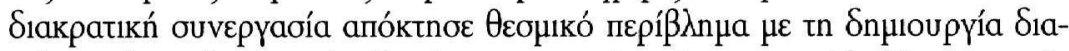

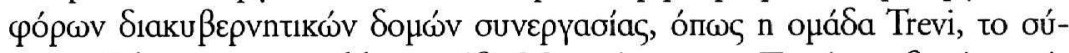

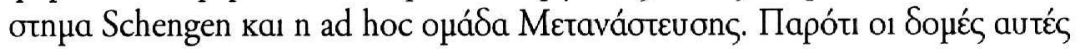

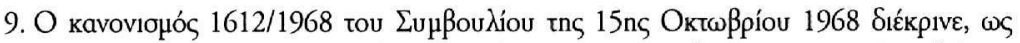

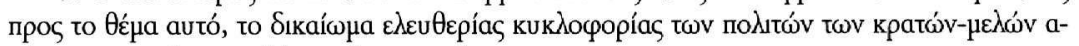

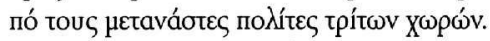

10. J. Huysmans, "The European Union and the securitization of migration», Journal of Common Market Studies, tóp. 38, ap. 5, 2000, б. 755.

11.S. Lavenex, "The Europeanisation of Refugee Policies. Normative challenges and institutional legacies», Journal of Common Market Studies, tóp. 39, ap. 5, 2001, o. 857. O-

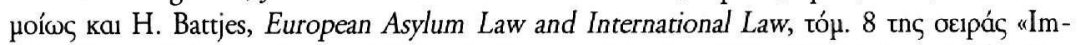
migration and Asylum Law and Policy in Europe», Martinus Nijhoff Publishers, Leiden/Boбడ́vn 2006, б. 25-33. 


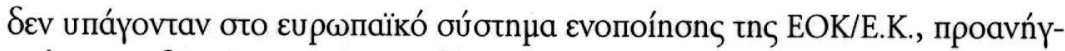

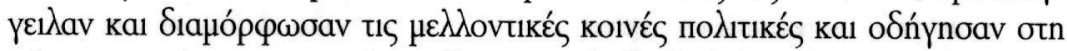

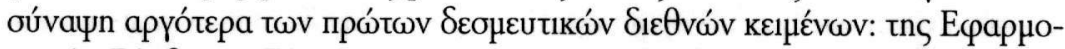

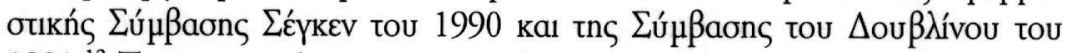

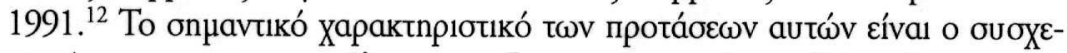

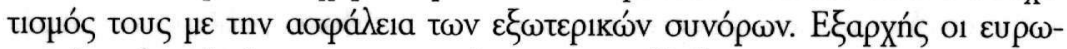

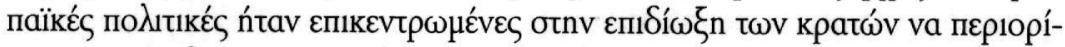

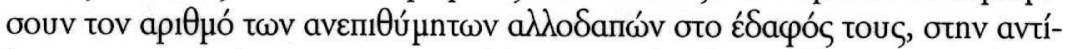

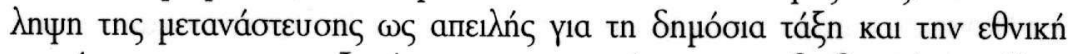

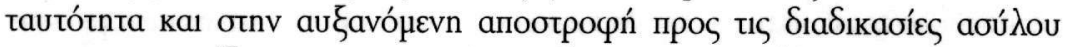

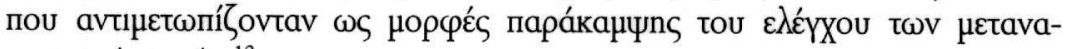

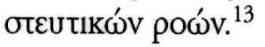

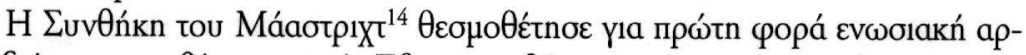

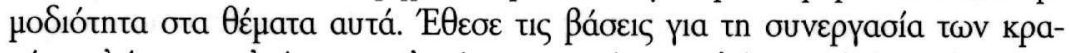

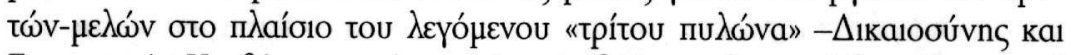

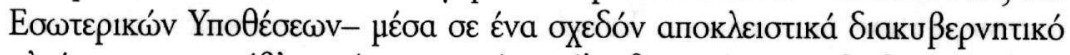

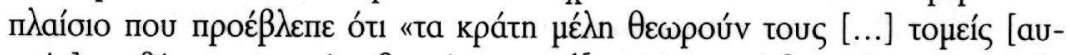

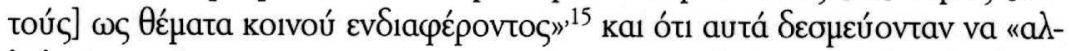

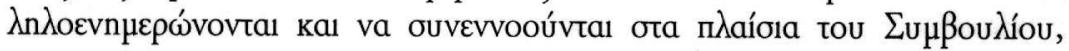

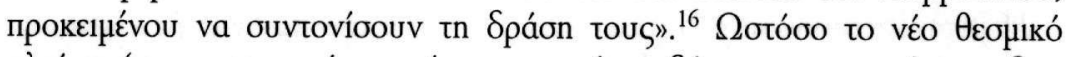

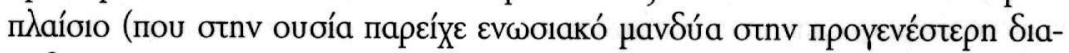

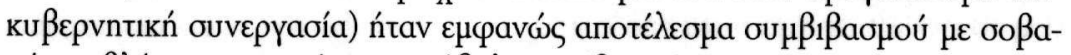

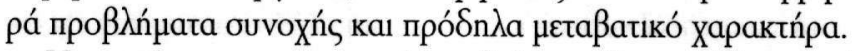

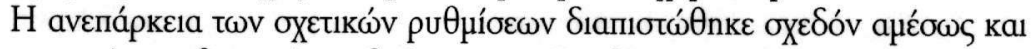

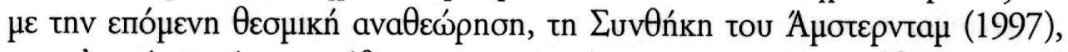

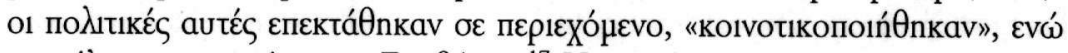

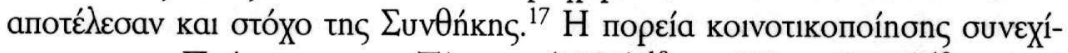

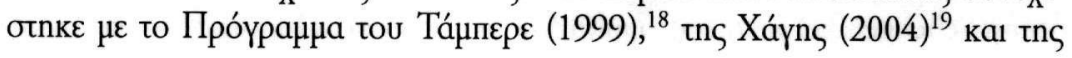

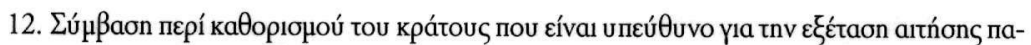

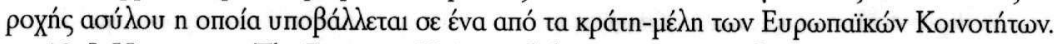

13. J. Huysmans, «The European Union and the securitization of migration», ó.m., б. 755-6.

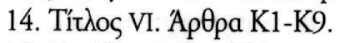

15. $\Sigma$ тo í $\delta$ io, áp $\theta$ po K 1.

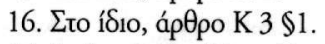

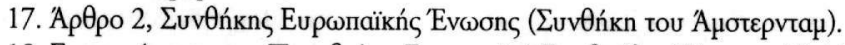

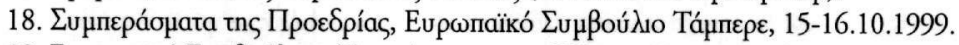

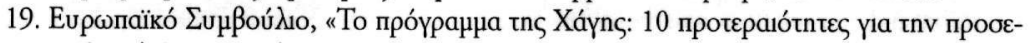
X́n пвvтавtía», 4-5. 11. 2004. 


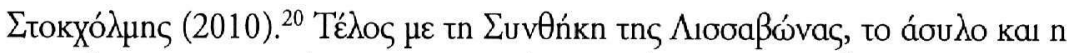

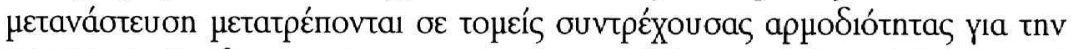

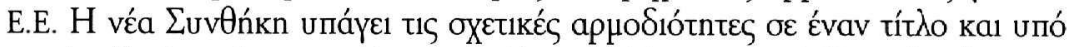

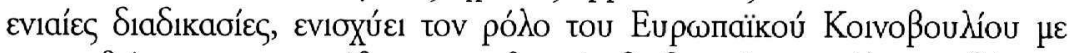

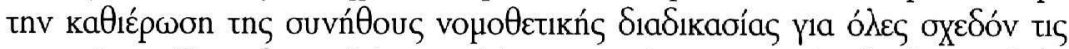

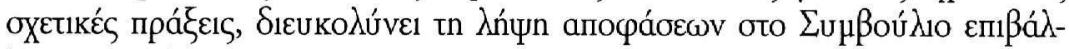

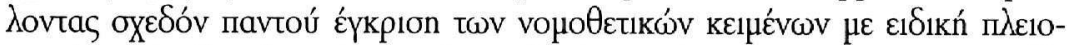

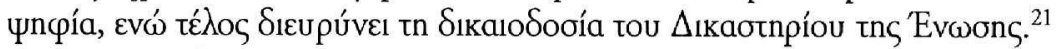

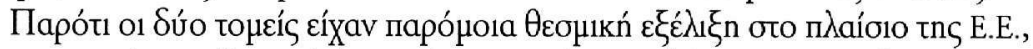

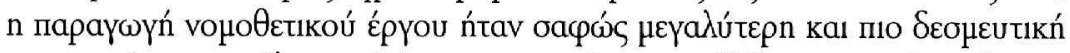

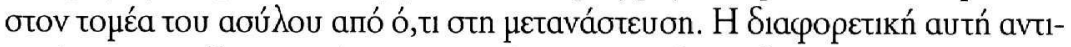

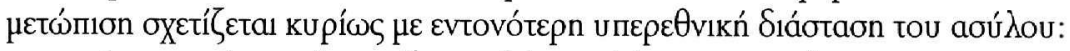

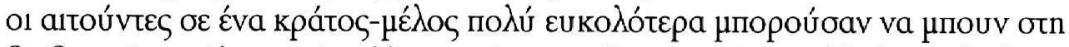

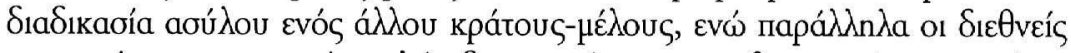

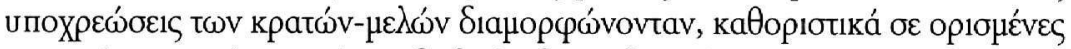

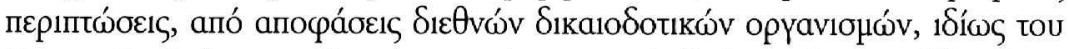

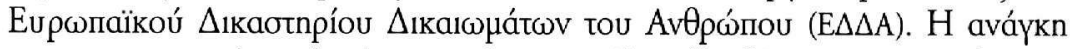

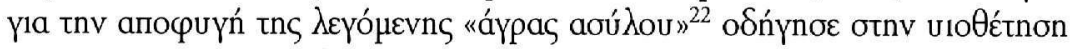

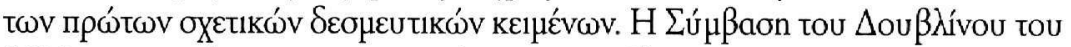

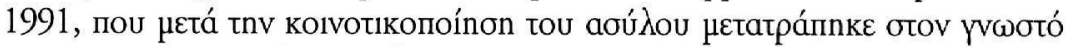

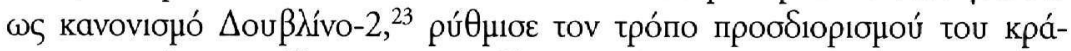

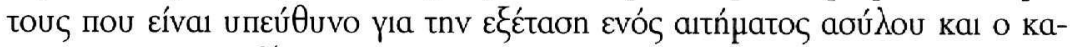

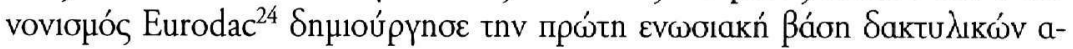

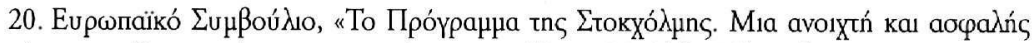

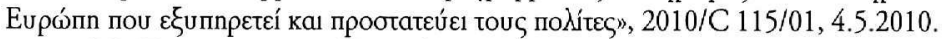

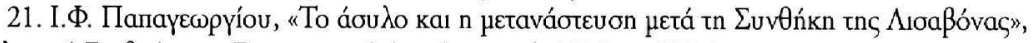

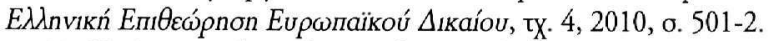

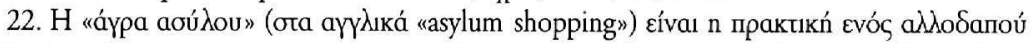

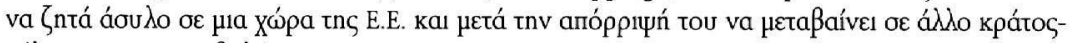

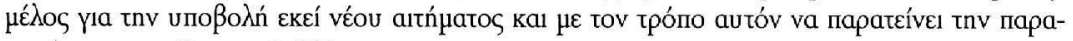

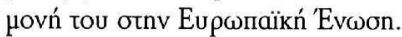

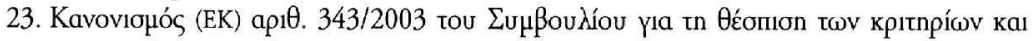

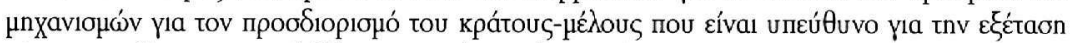
aítnonş ađứ

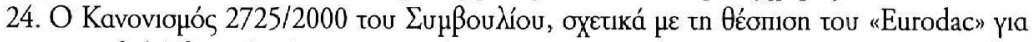

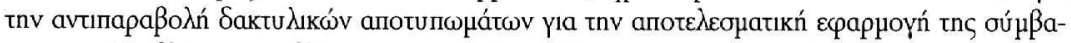

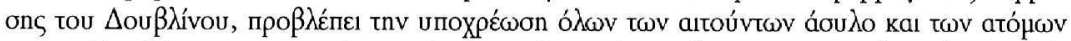

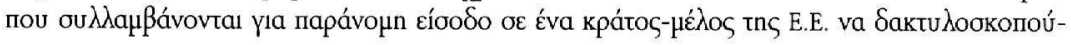




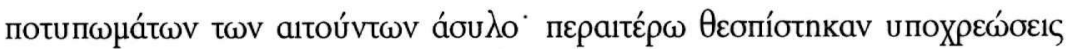

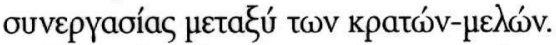

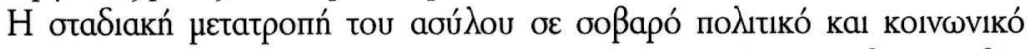

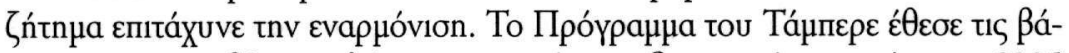

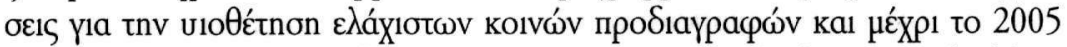

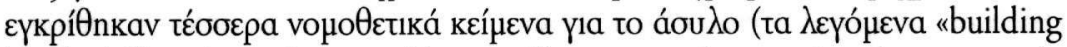

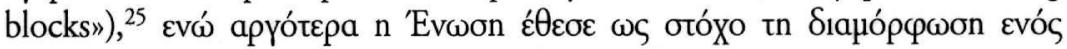

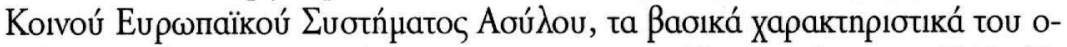

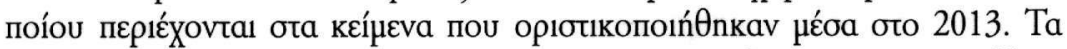

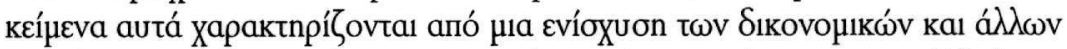

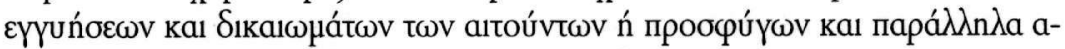

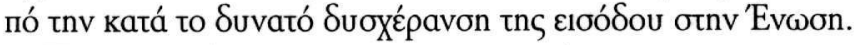

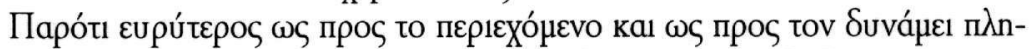

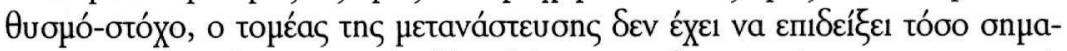

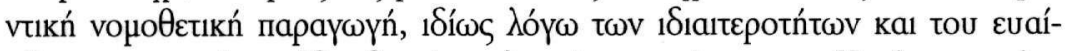

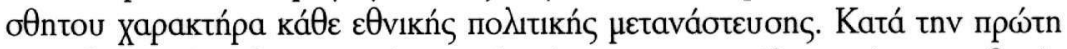

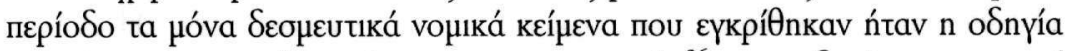

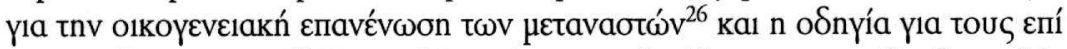

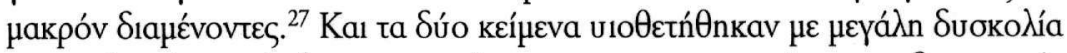

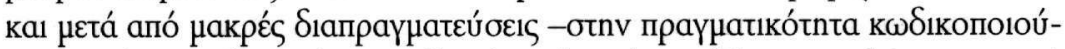

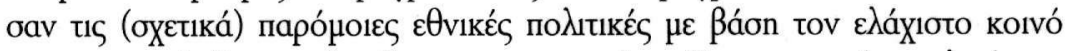

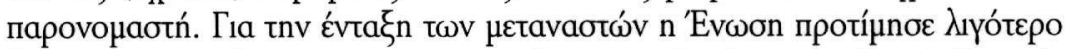

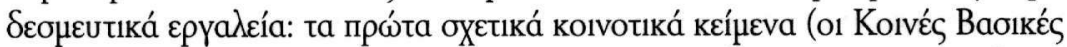

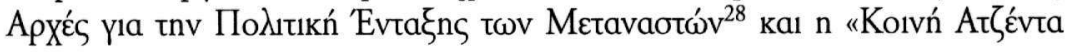

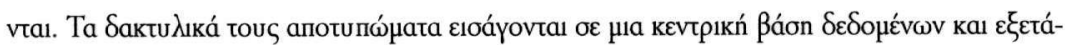

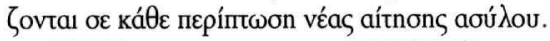

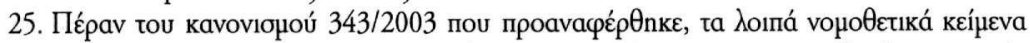

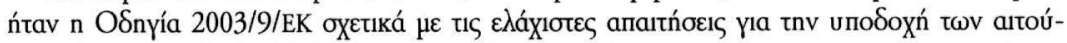

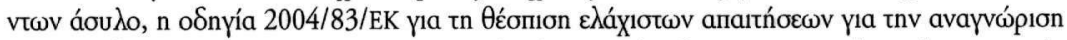

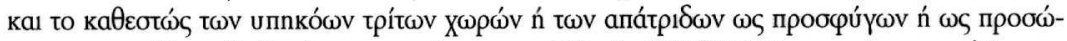

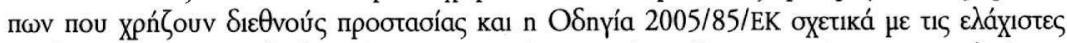

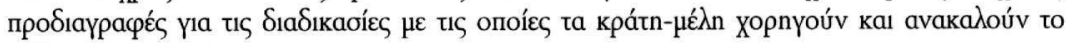

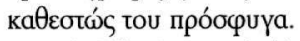

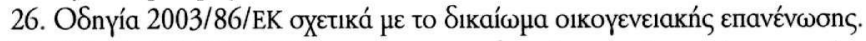

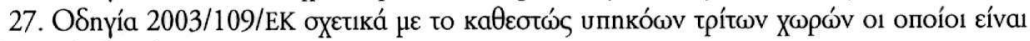

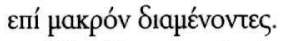

28. «Common basic principles for immigrant integration policy in the European Union». 


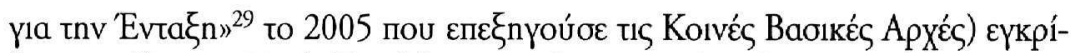

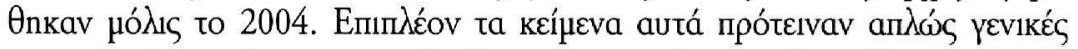

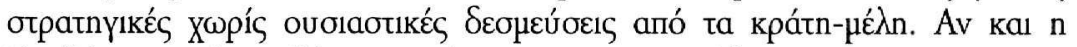

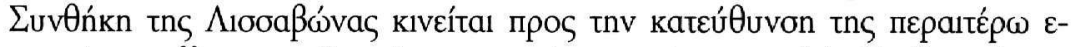

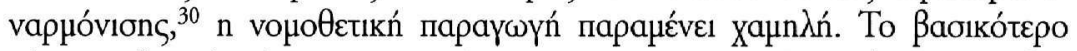

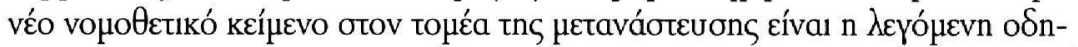

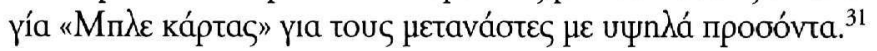

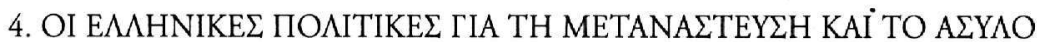

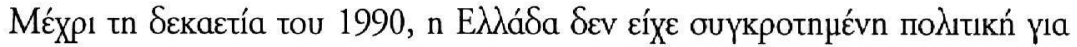

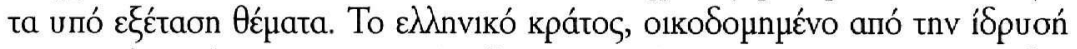

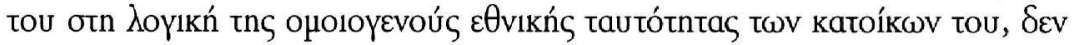

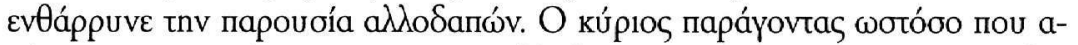

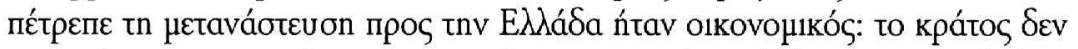

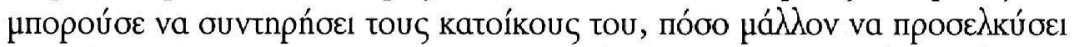

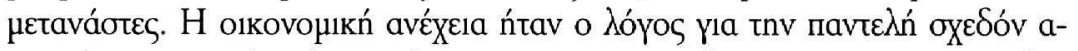

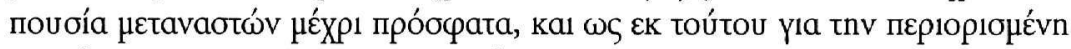

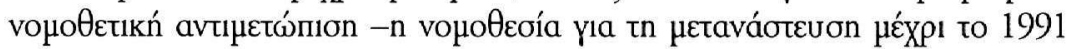

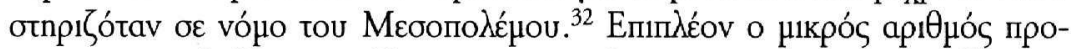

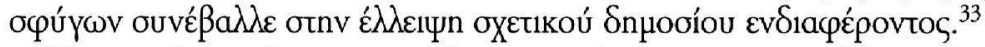

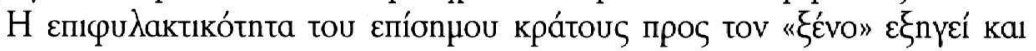

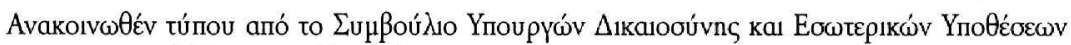
tns 19.11.2004. 'Еүүрачо 4615/04.

29. «A common agenda for integration framework for the integration of third-country nationals in the European Union». Communication from the Commission to the Council, the European Parliament, the European Economic and Social Committee and the Committee of the Regions. Brussels, 1.9.2005 COM(2005) 389 final.

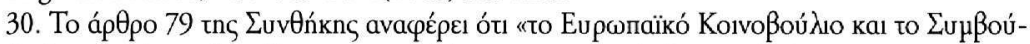

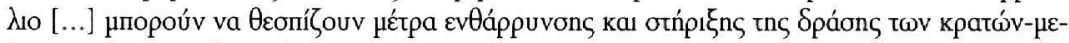

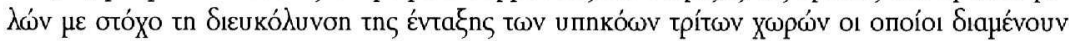

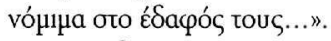

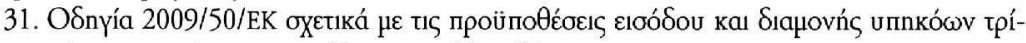

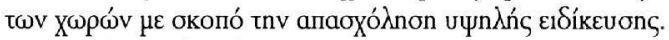

32. Nópoç 4310/1929.

33. A. Skodras - N. Sitaropoulos, "Why Greece is not a safe country host for refugees», International Journal of Refugee Law, tón. 16, ap. 1, 2004, o. 49. 


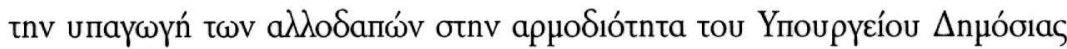

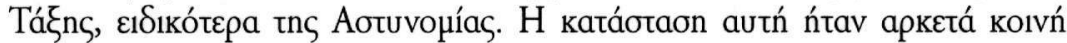

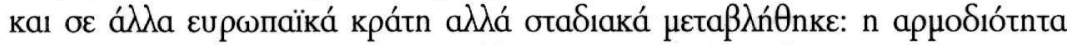

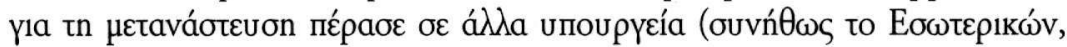

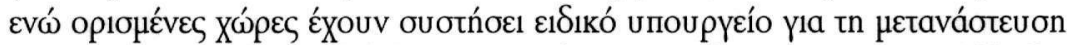

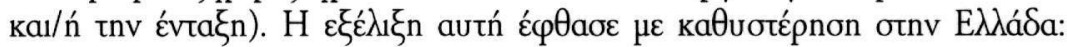

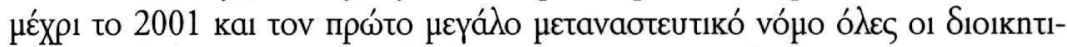

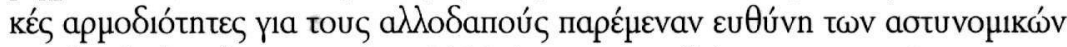

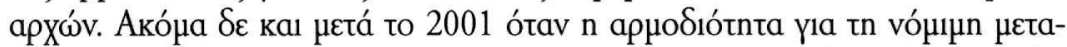

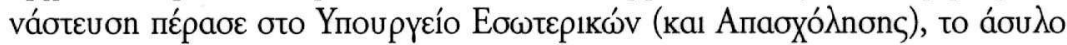

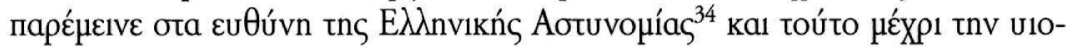

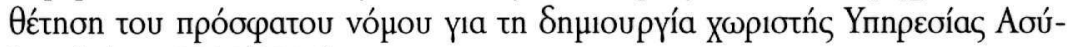
גou (vónos 3907/2011).

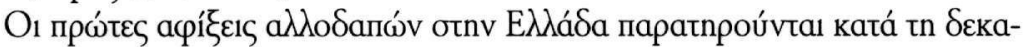

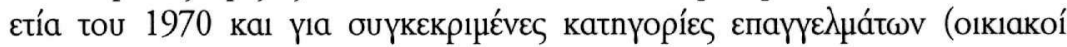

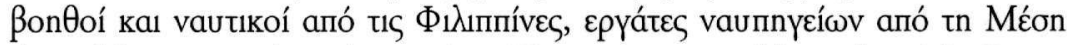

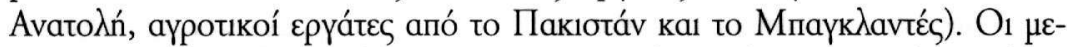

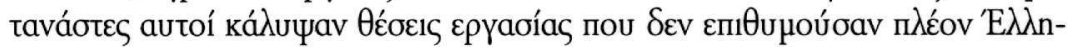

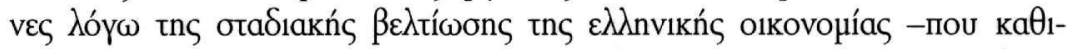

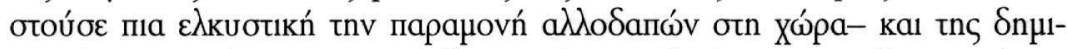

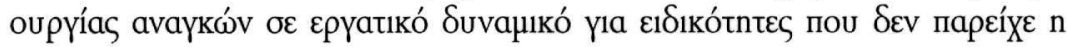

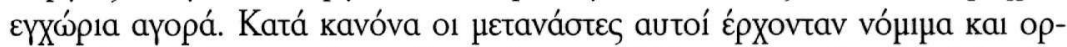

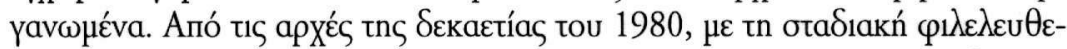

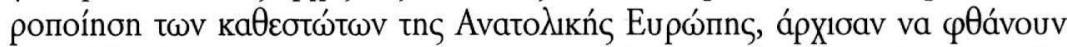

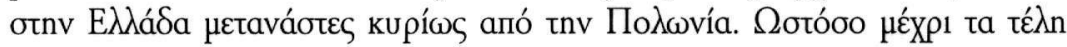

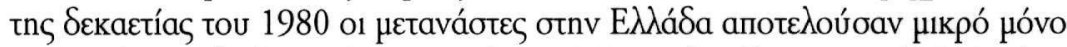

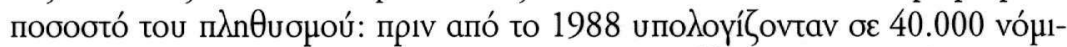

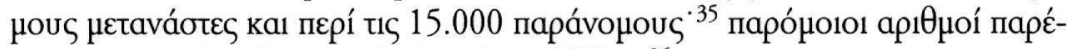
Xovta1 kaı aпó to Yпoupycío $\Delta$ nuóoias Tákns. ${ }^{36}$

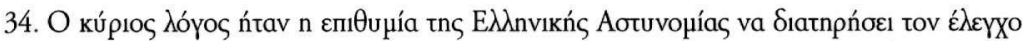

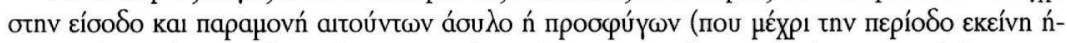

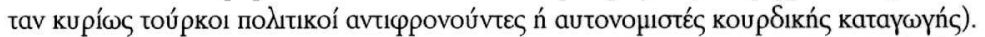

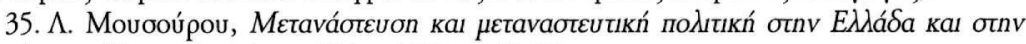

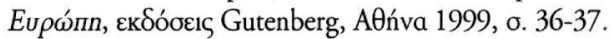

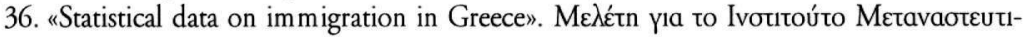

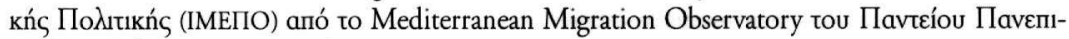
ornuíou, AӨńva. 15.11.2004, o. 10-11. 


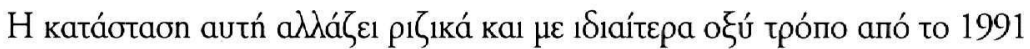

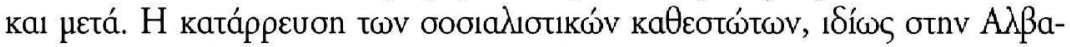

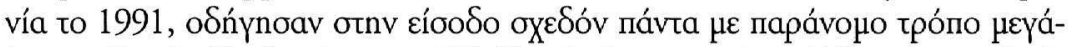

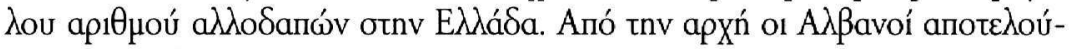

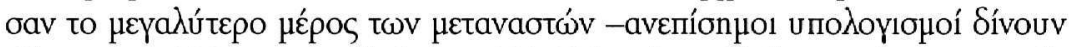

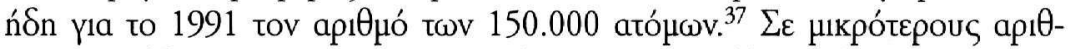

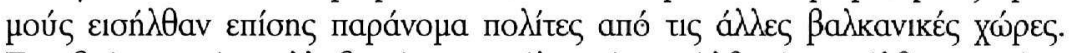

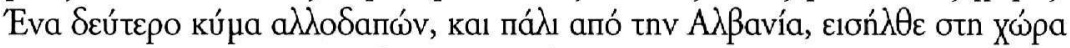

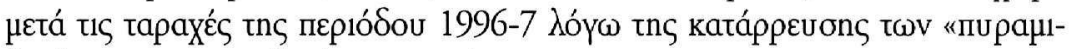

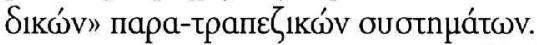

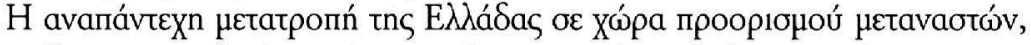

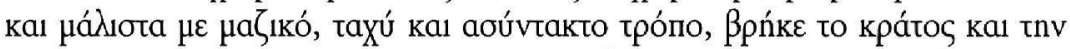

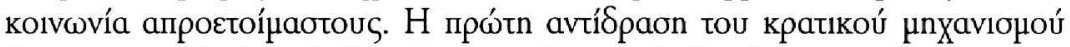

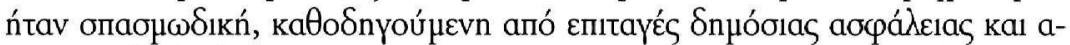

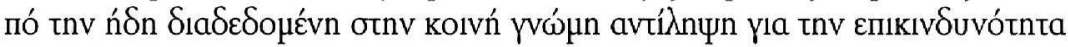

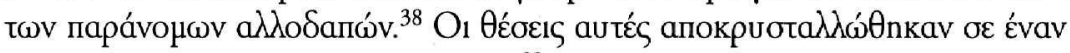

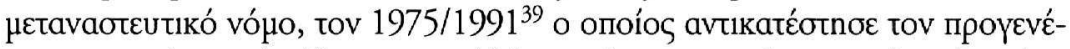

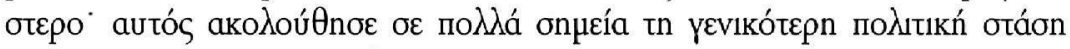

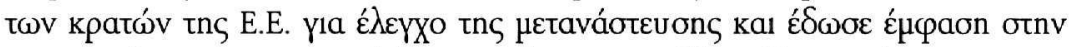

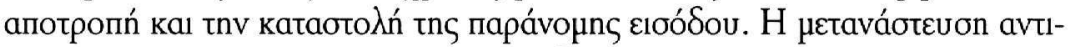

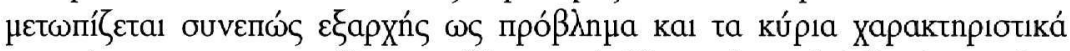

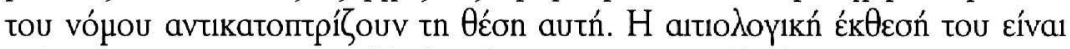

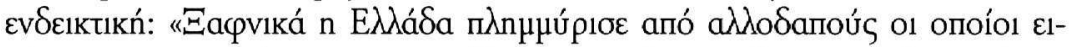

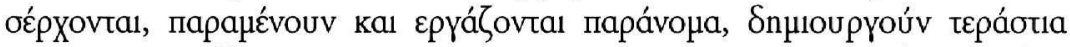

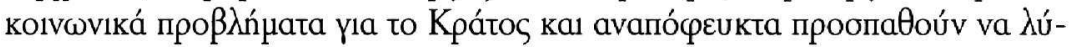

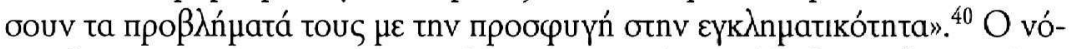

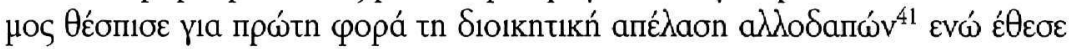

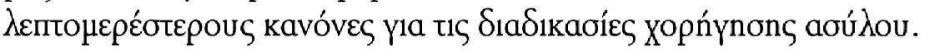

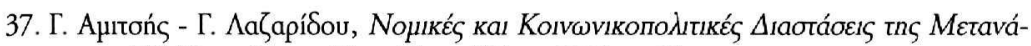

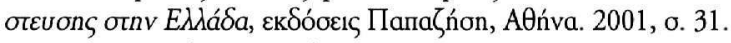

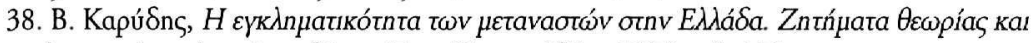

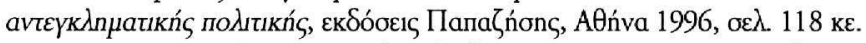

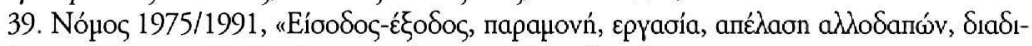

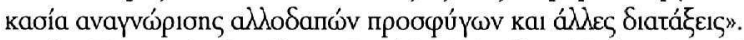

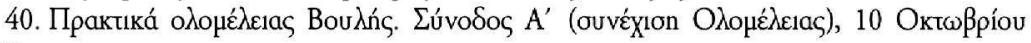
1991.

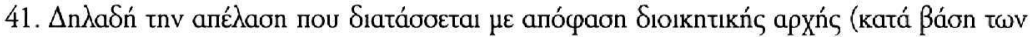

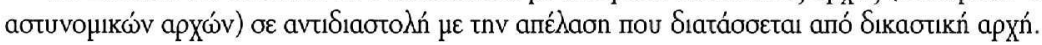




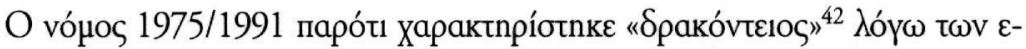

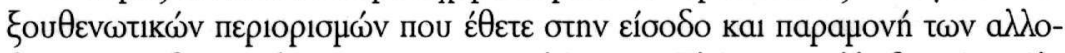

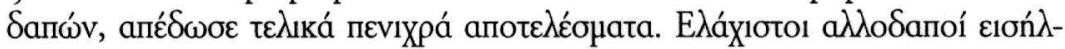

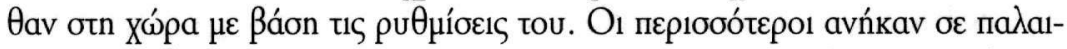

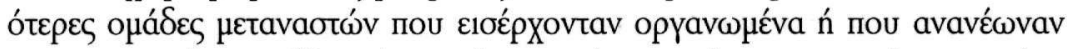

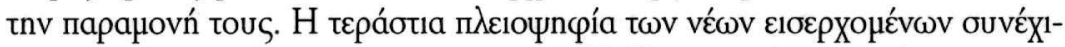

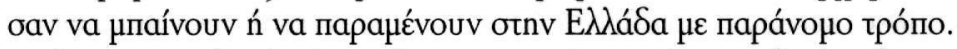

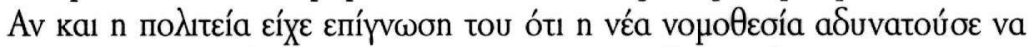

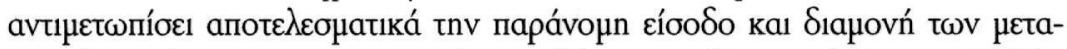

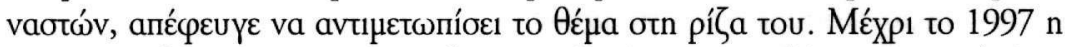

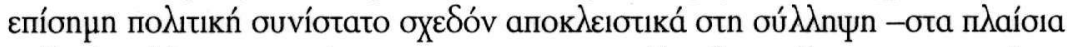

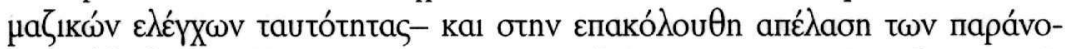

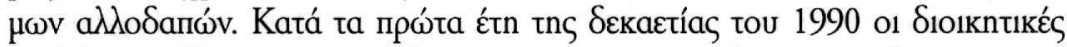

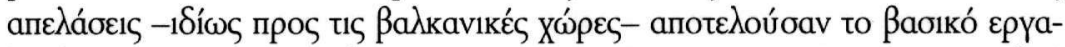

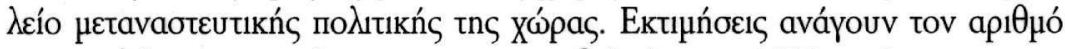

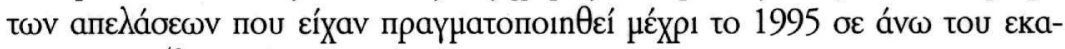
topuupíou. ${ }^{43}$

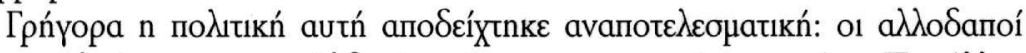

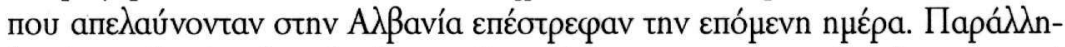

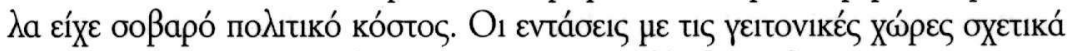

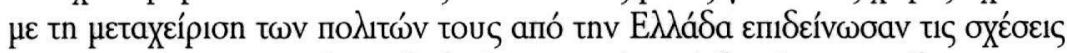

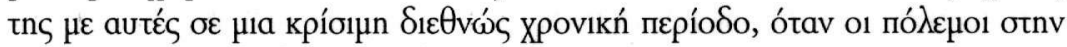

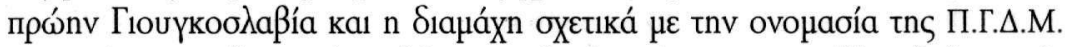

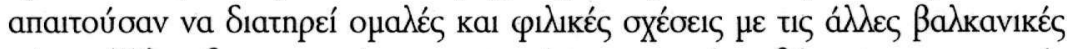

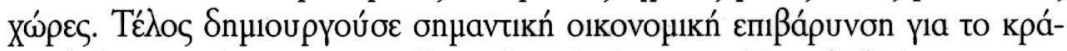

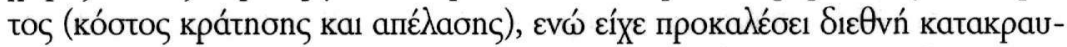

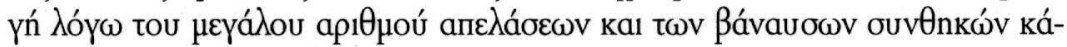

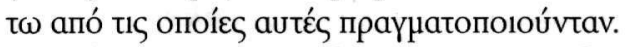

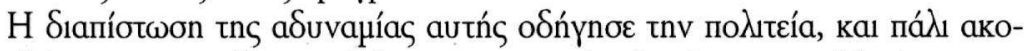

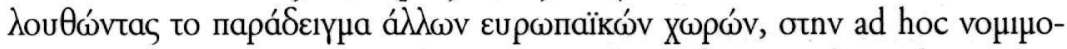

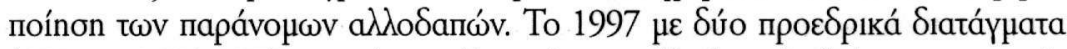

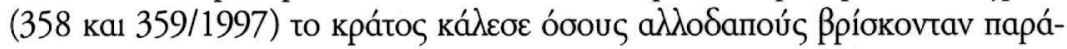

42. Nicholas Sitaropoulos, "Modern Greek Asylum Policy and Practice in the Context of the Relevant European Development», Journal of Refugee Studies, tój. 13, ap. 1, (2000) o. 110.

43. B. Edwards, «Immigration into Greece, 1990-2003: a Southern European Paradigm?», paper presented at the UNECE European Population Forum 2004, Geneva (CH) 12-14/1/2004, http://aei.pitt.edu/1078/1/UNECE_paperV3-1.pdf (прóoßaon 14.01.2013). 


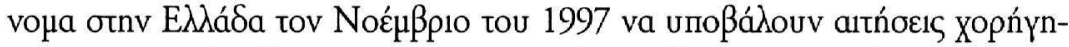

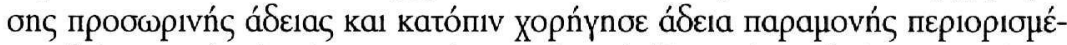

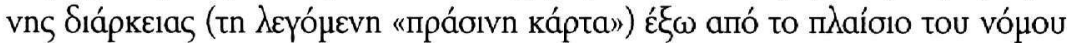

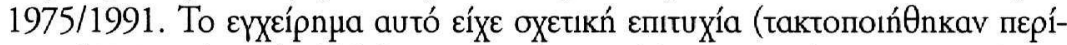

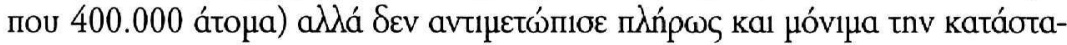

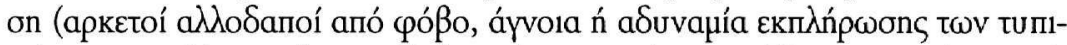

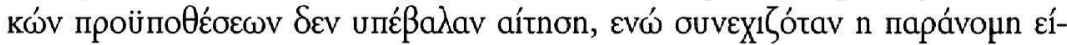

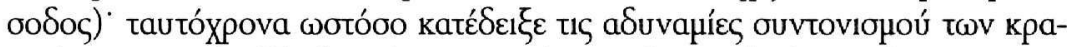

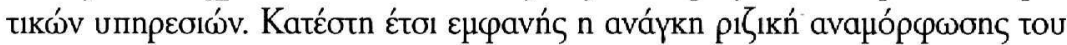

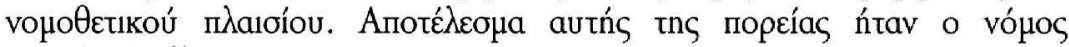
$2910 / 2001{ }^{44}$

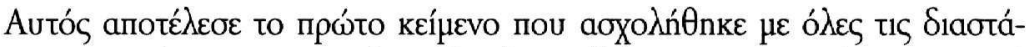

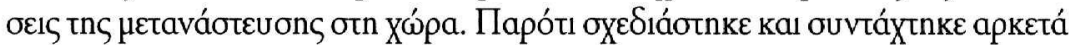

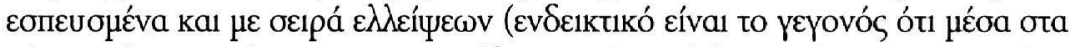

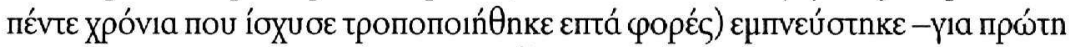

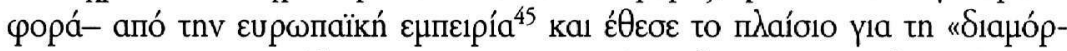

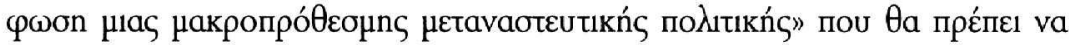

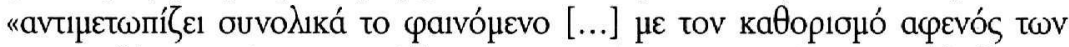

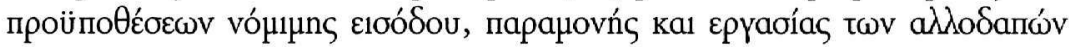

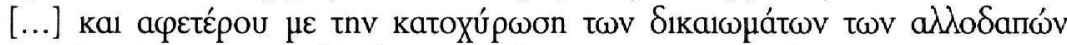

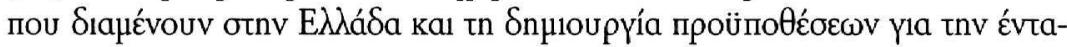

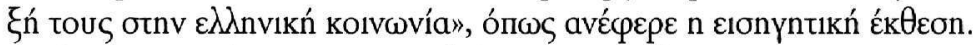

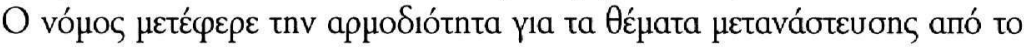

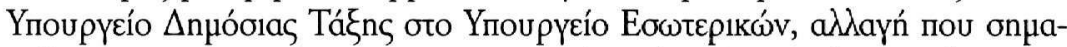

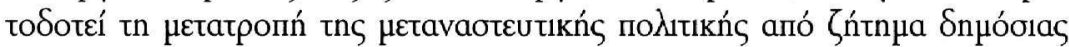

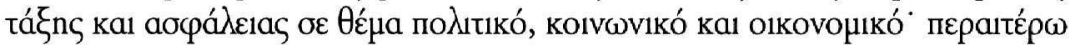

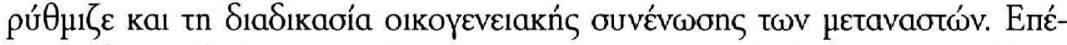

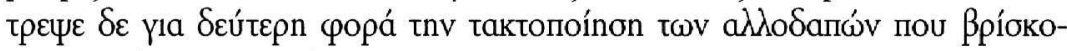

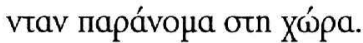

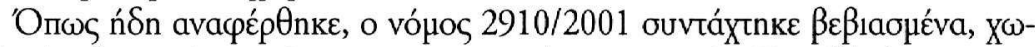

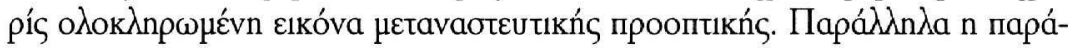

44. N. 2910/2001, ФEK A; 91 anó 27.4.2001.

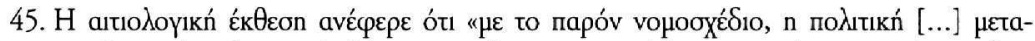

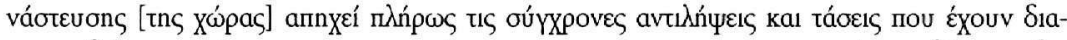

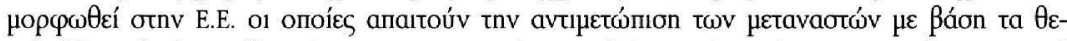

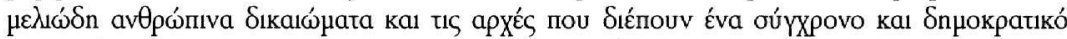
крátos Sıkaíou». 


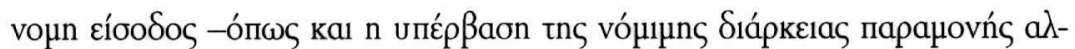

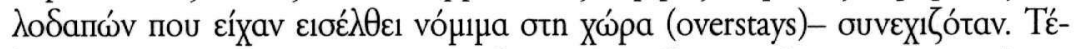

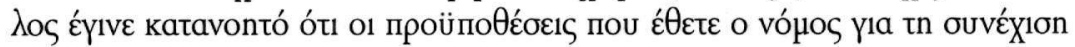

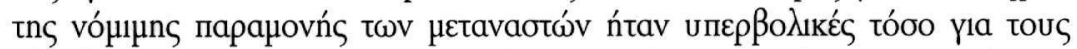

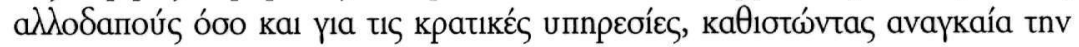

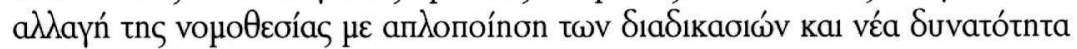
vouнonoínons.

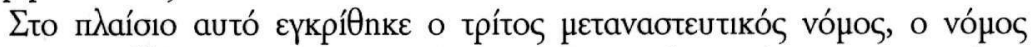

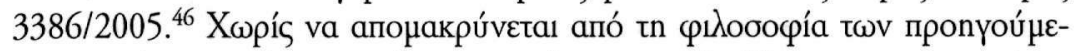

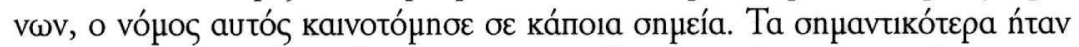

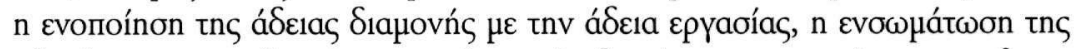

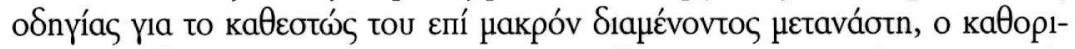

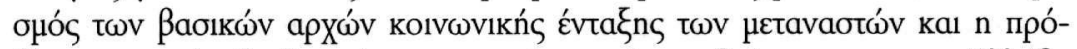

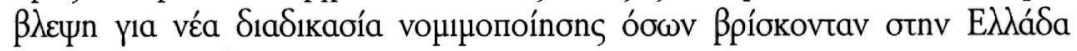
otı 31.12.2004.

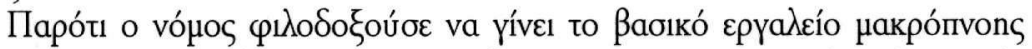

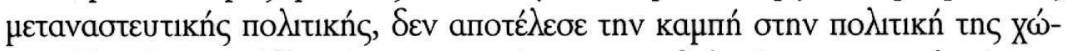

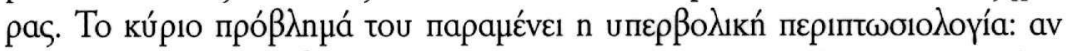

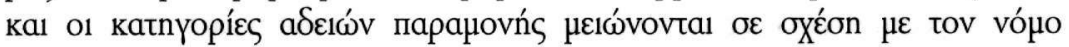

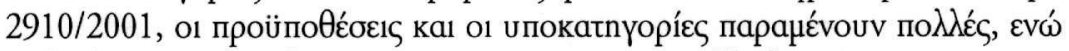

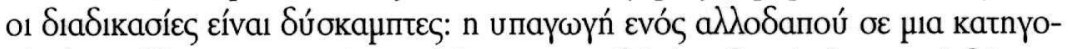

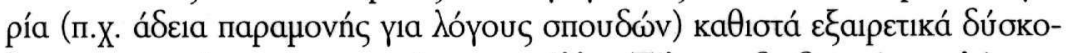

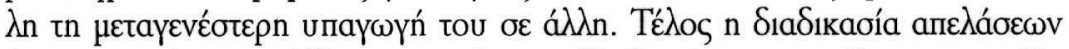

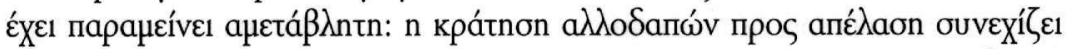

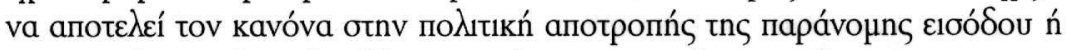

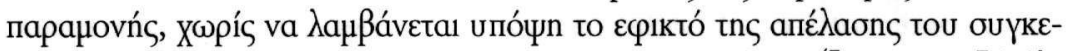

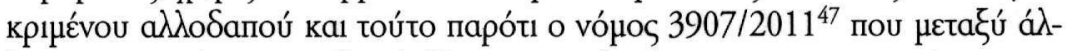

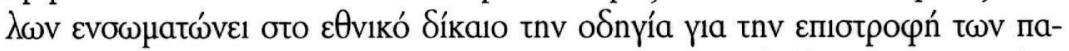

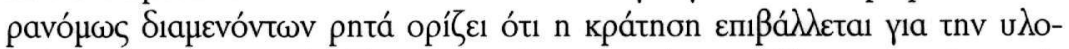

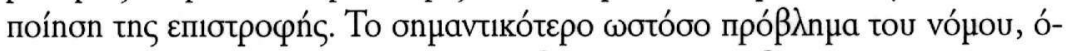

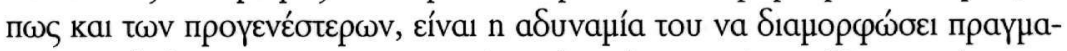

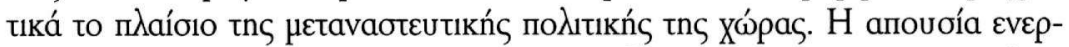

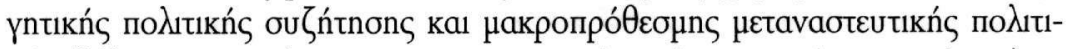

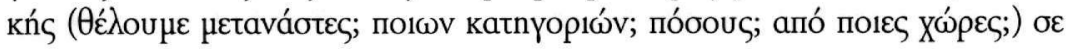

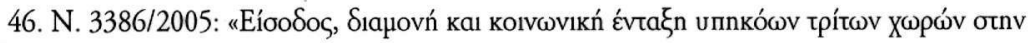

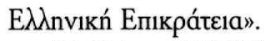

47. Nónos 3907/2011. ФEK A-7/26.01.2011. 


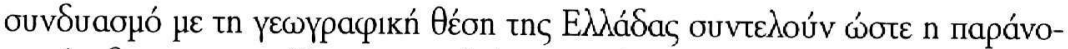

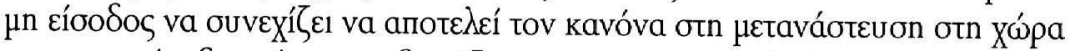

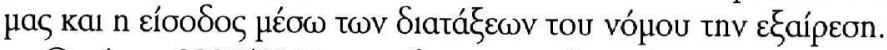

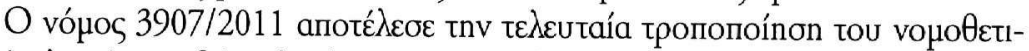

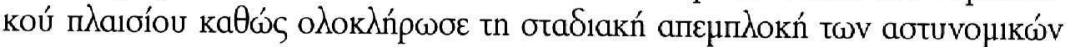

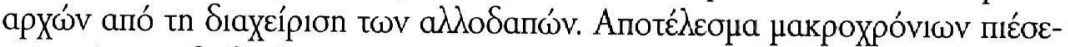

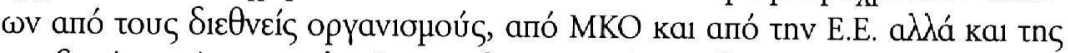

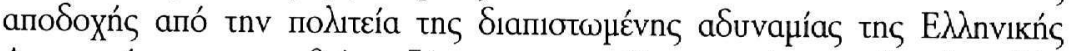

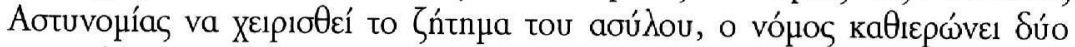

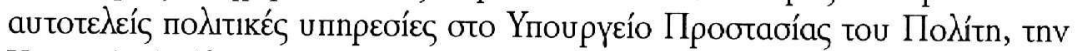

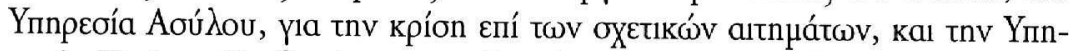

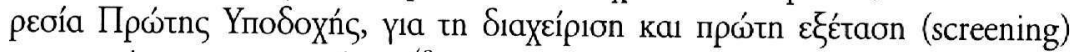

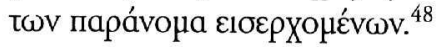

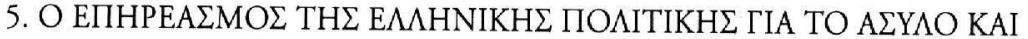

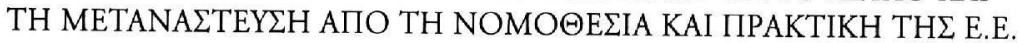

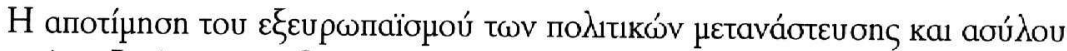

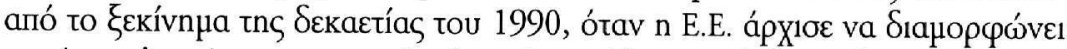

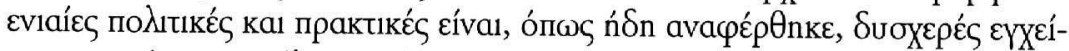

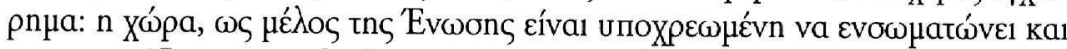

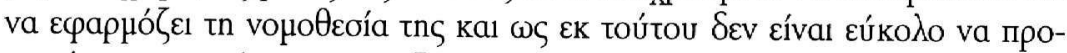

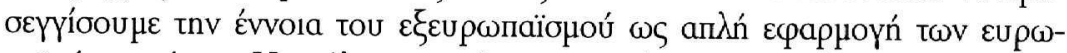

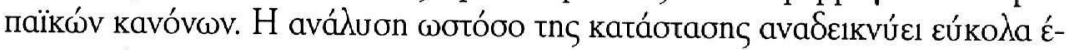

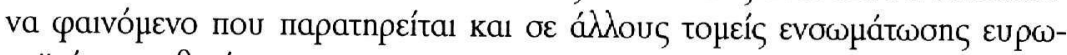

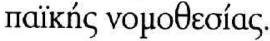

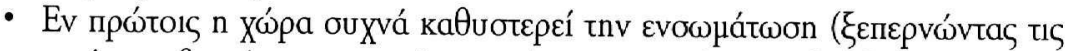

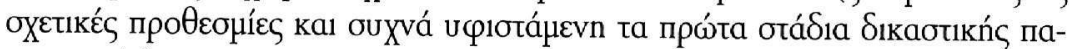
рапонпń().

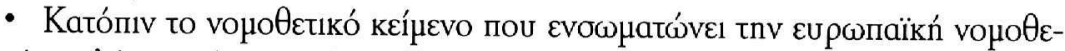

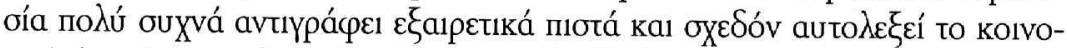

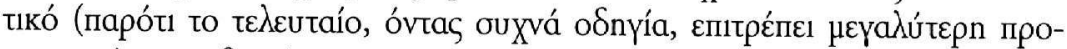

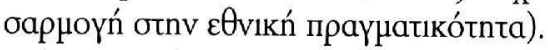

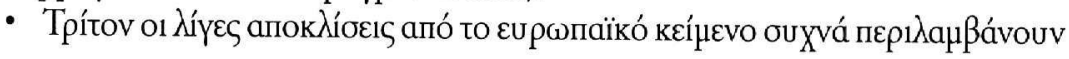

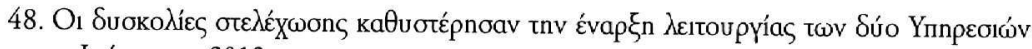

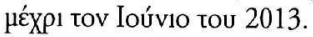




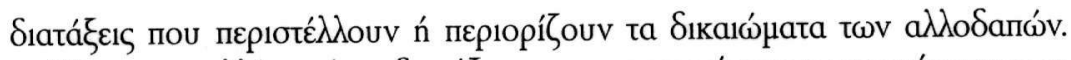

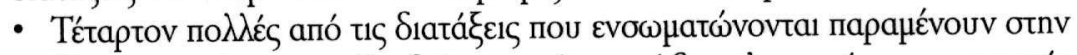

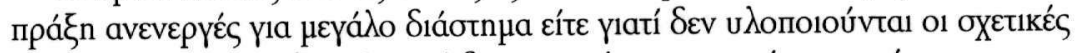

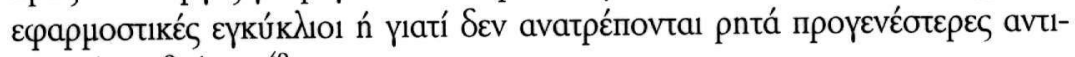

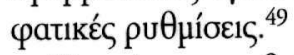

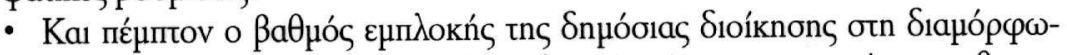

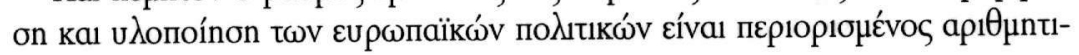
ká ka1 поюотı́á.

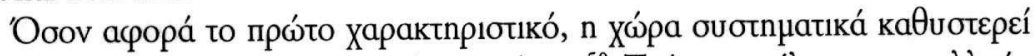

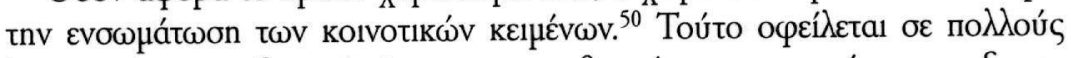

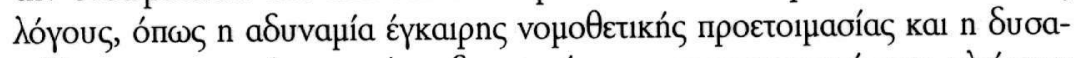

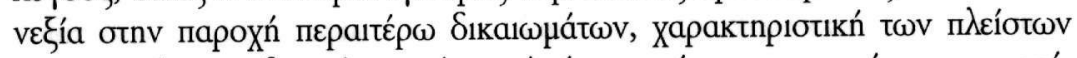

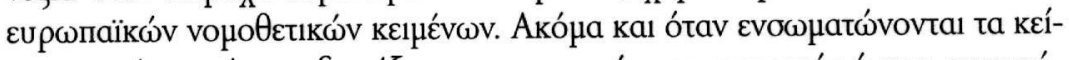

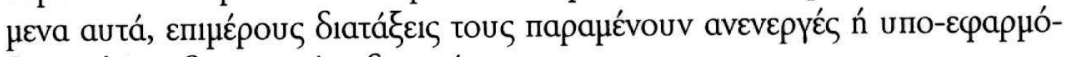

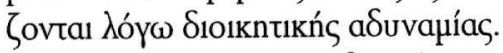

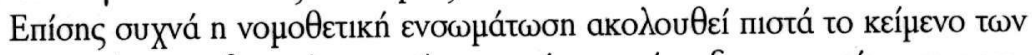

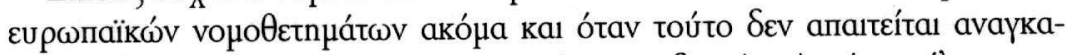

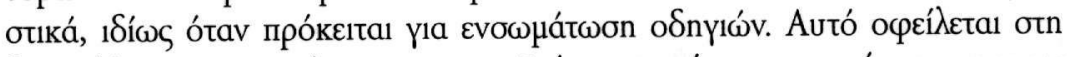

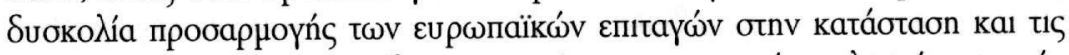

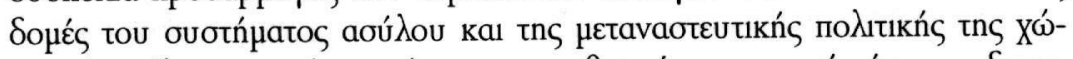

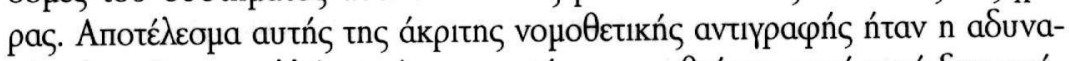

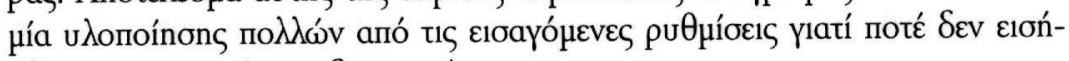

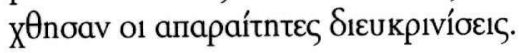

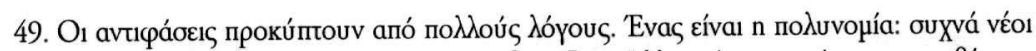

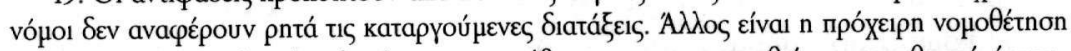

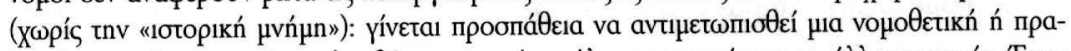

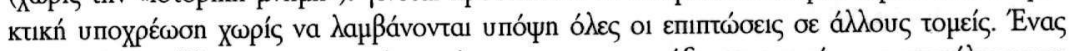

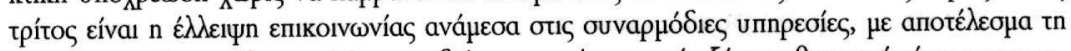

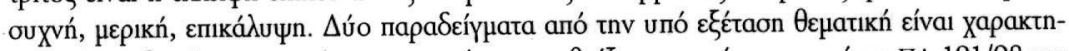

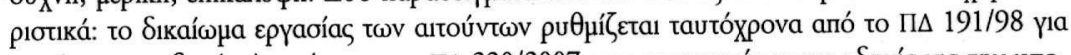

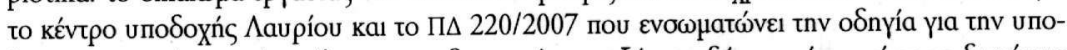

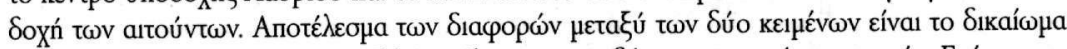

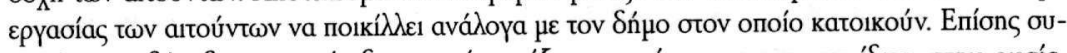

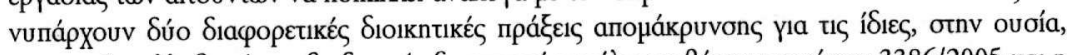

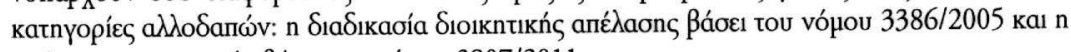

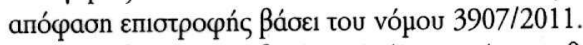

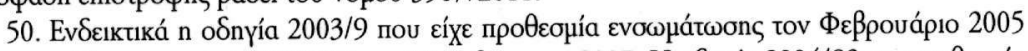

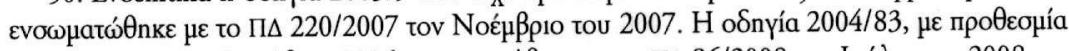

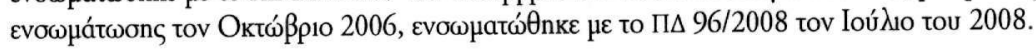




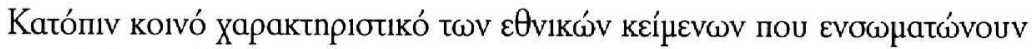

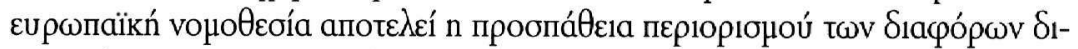

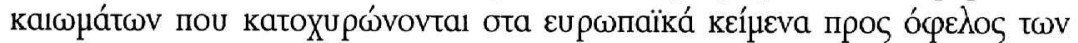

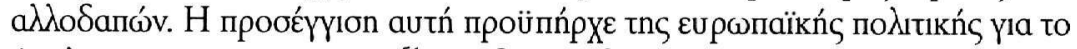

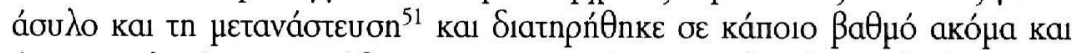

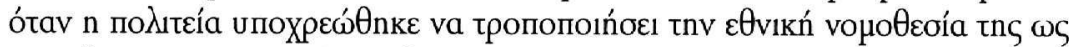

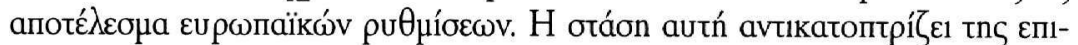

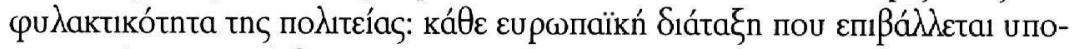

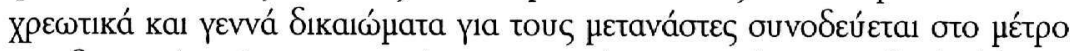

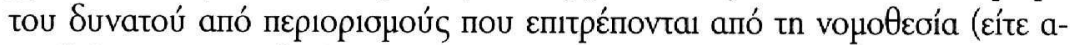

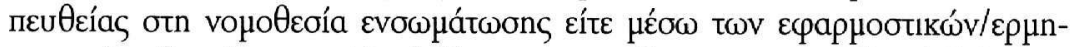

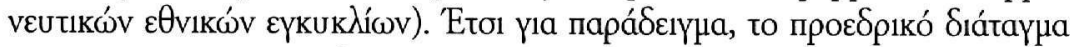

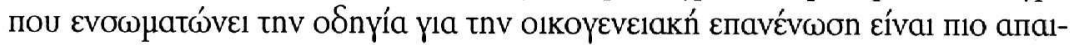

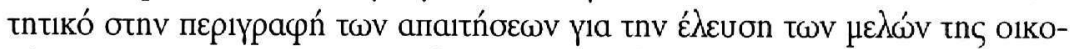

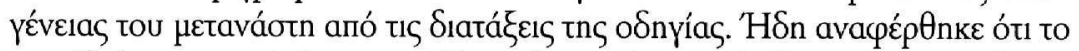

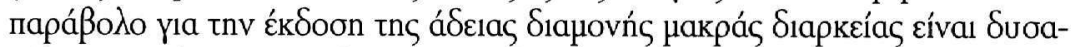

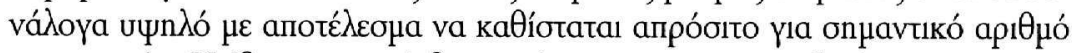

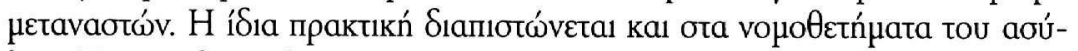

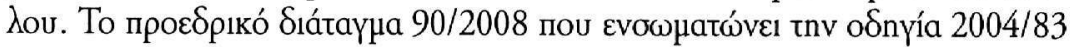

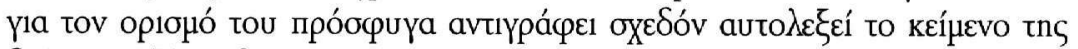

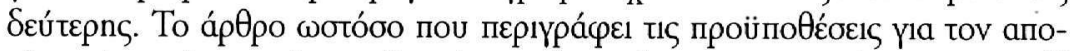

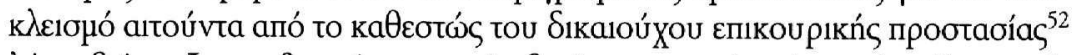

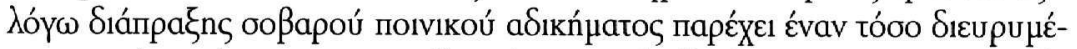

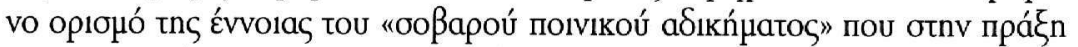

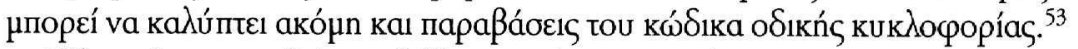

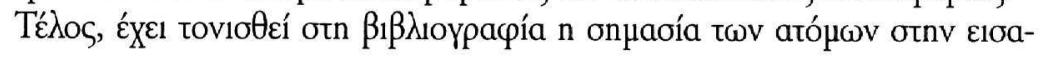

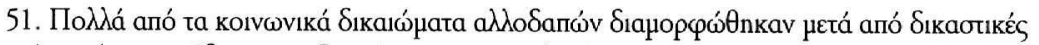

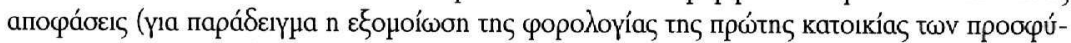

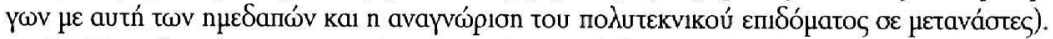

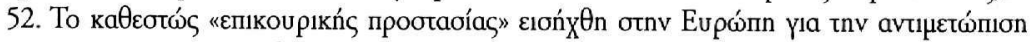

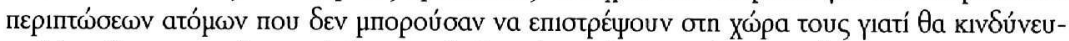

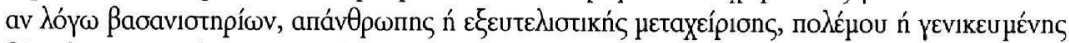

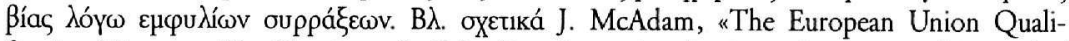
fication Directive: The Creation of a Subsidiary Protection Regimen, International Journal of Refugee Law, tóp. 17, ap. 3, 2005, o. 461-516.

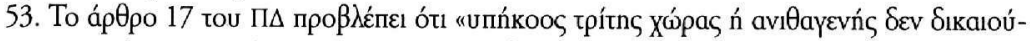

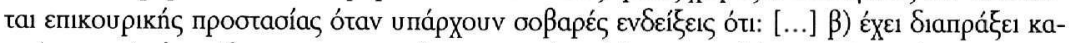

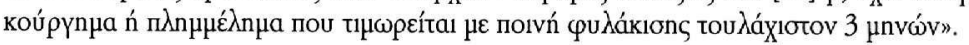




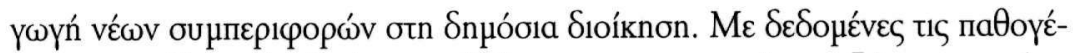

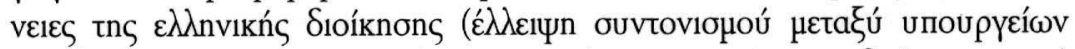

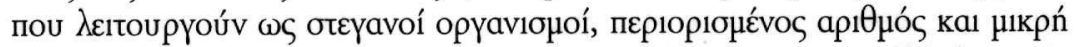

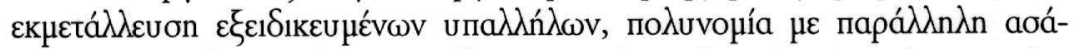

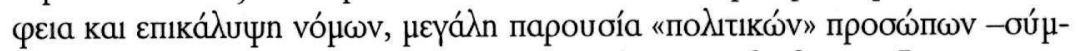
ßou

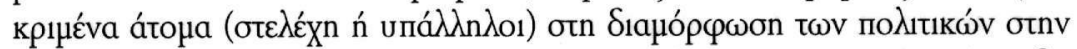

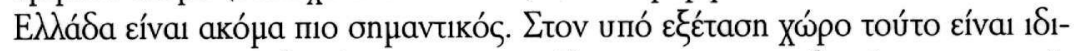

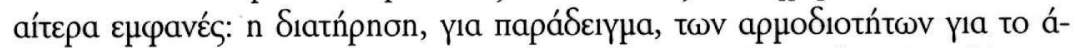

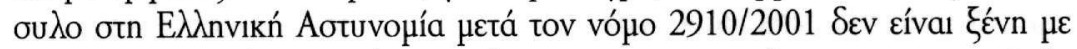

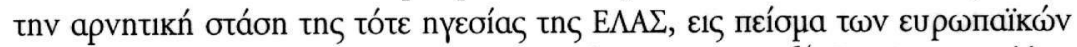

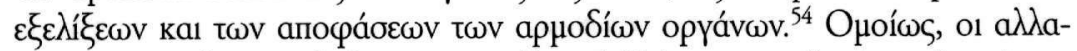

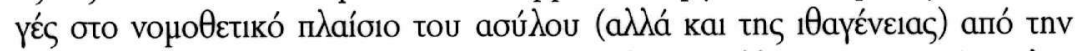

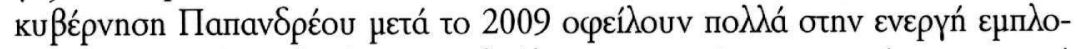

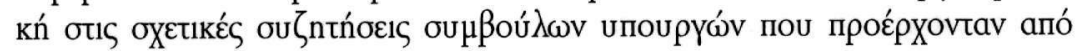

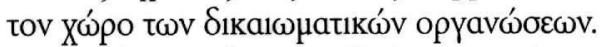

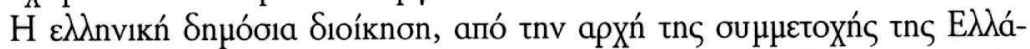

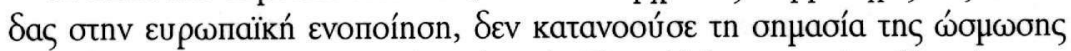

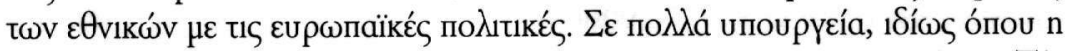

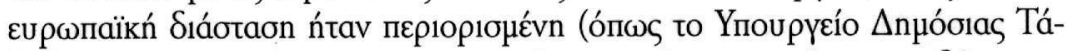

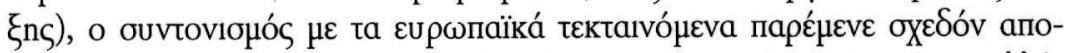

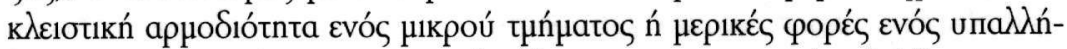

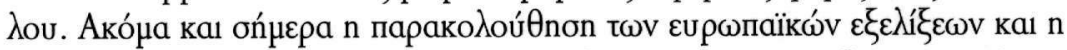

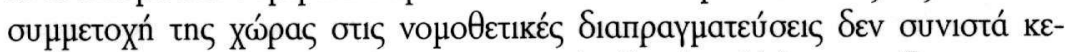

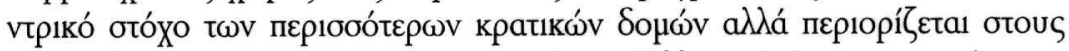

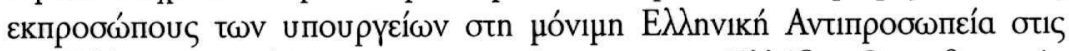

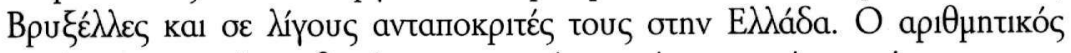

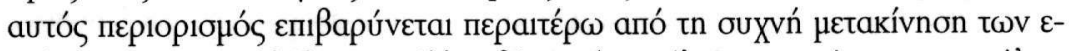

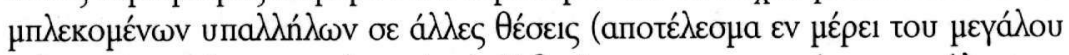

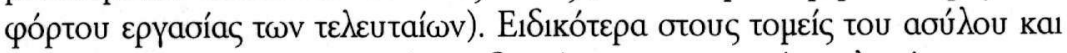

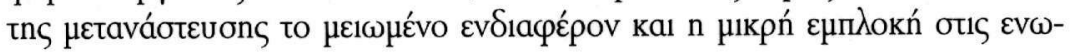

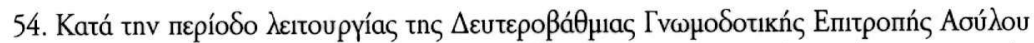

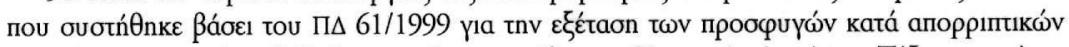

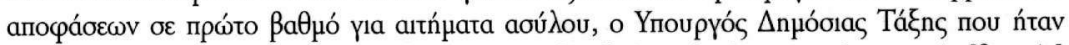

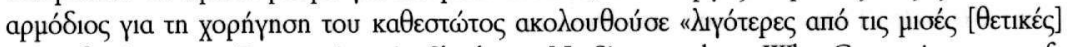

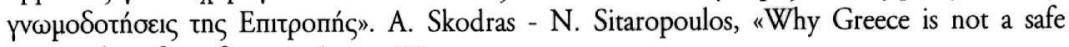
country host for refugees», ó.I., б. 39. 


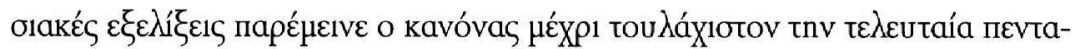

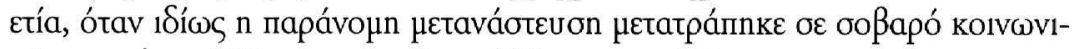

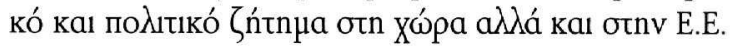

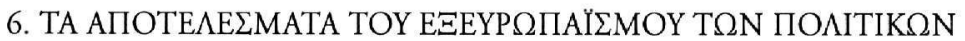

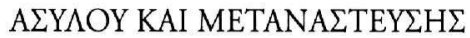

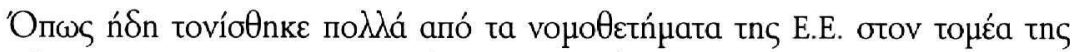

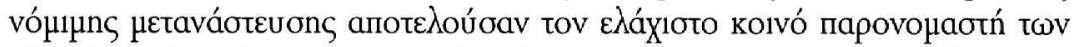

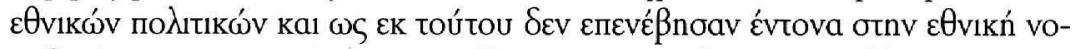

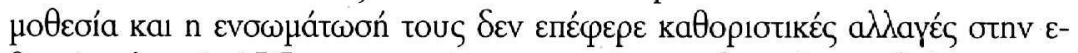

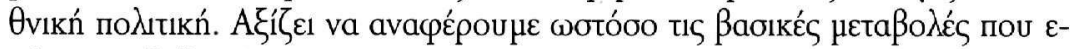

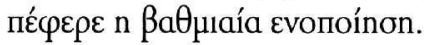

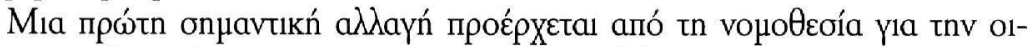

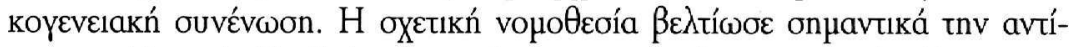

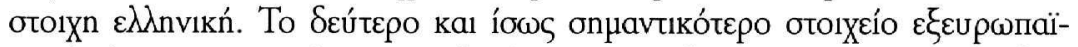

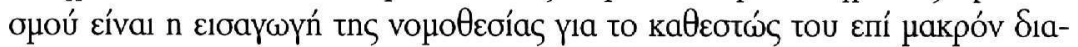

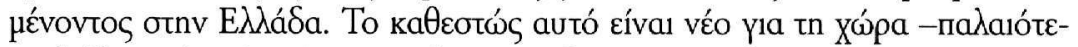

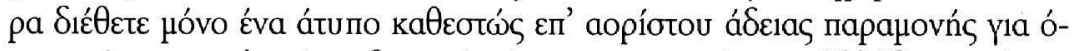

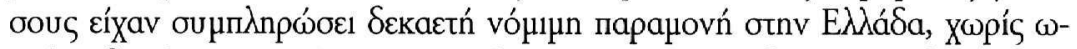

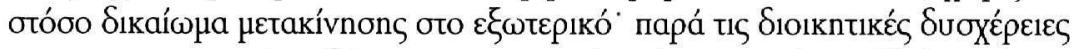

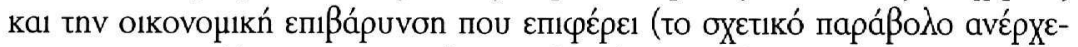

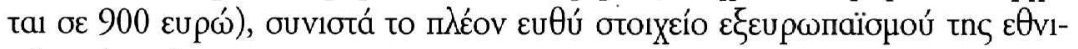

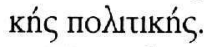

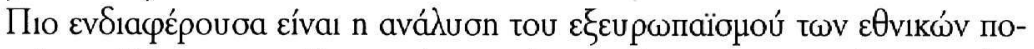

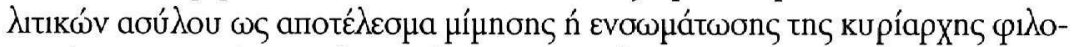

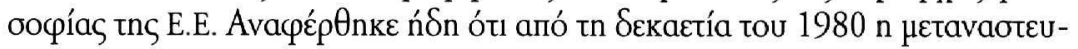

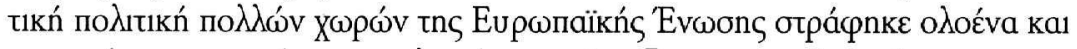

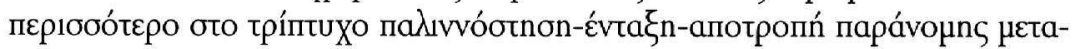

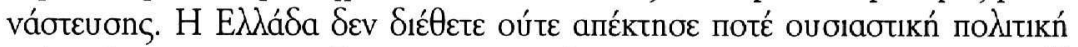

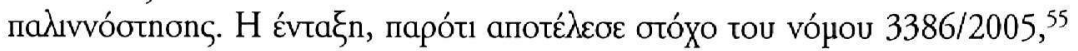

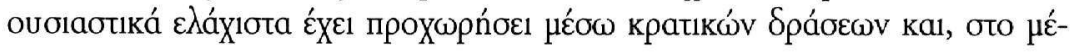

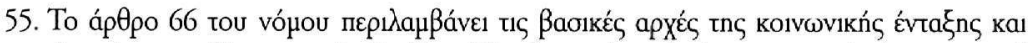

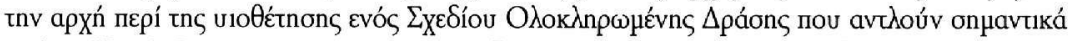

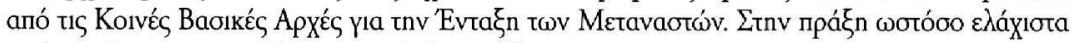

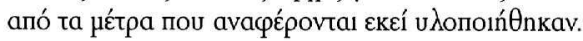




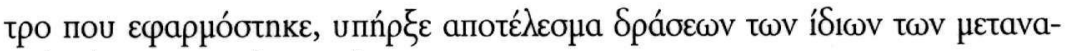

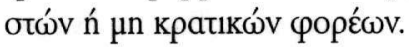

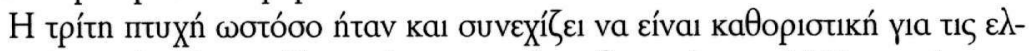

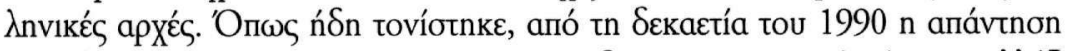

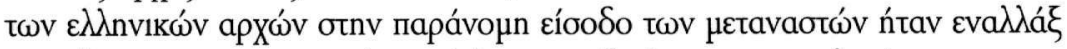

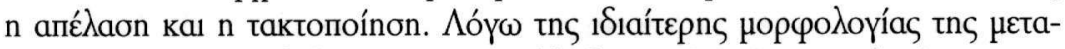

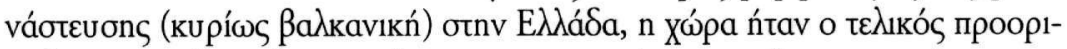

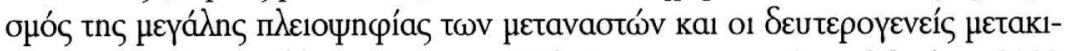

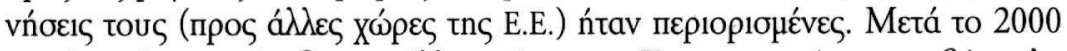

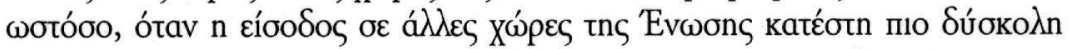

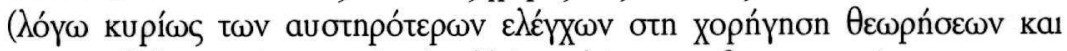

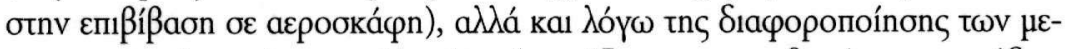

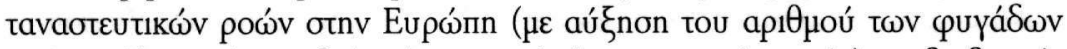

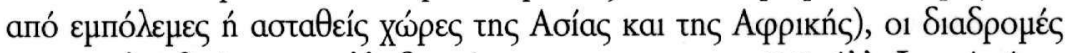

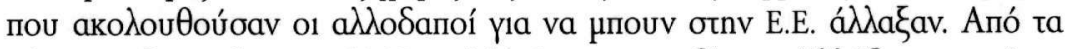

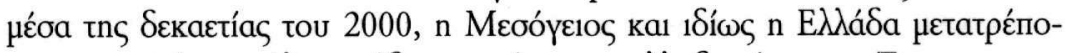

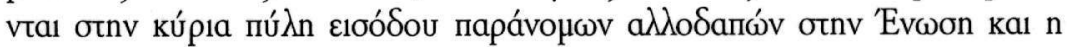

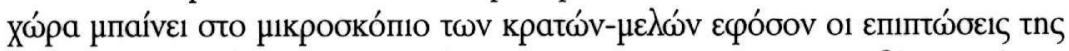
парávoun

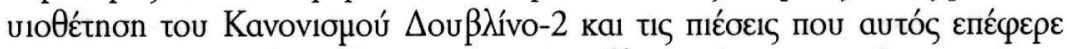

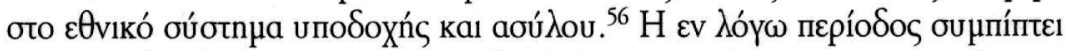

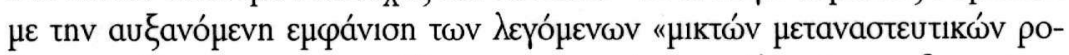

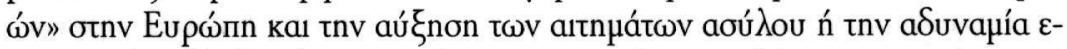

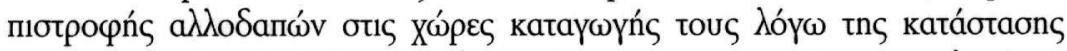

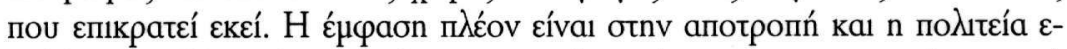

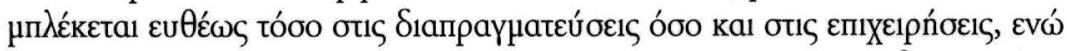

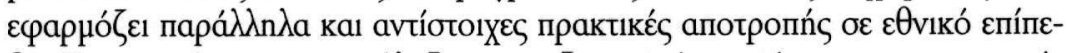

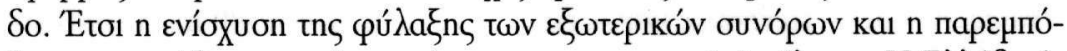

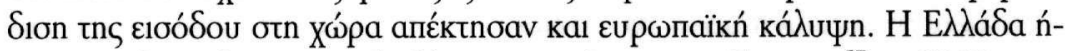
tav n пр

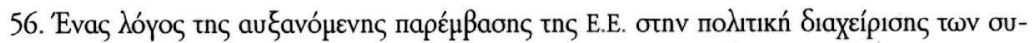

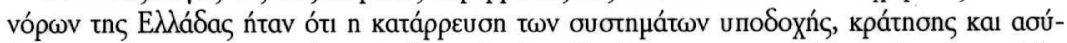

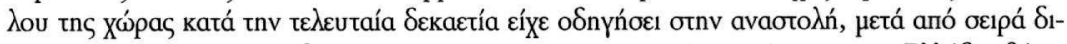

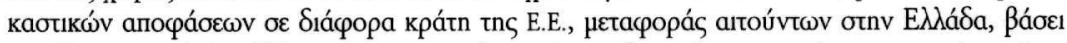

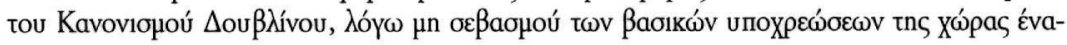

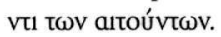

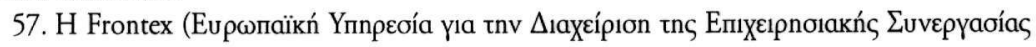




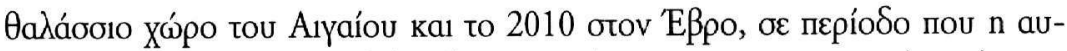

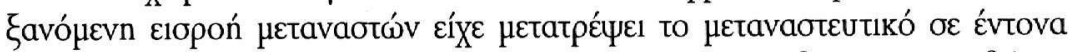

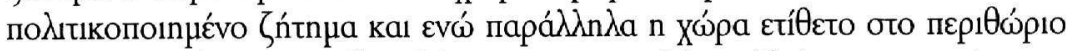

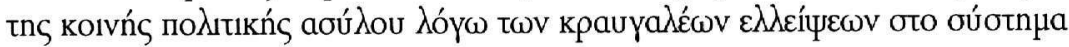

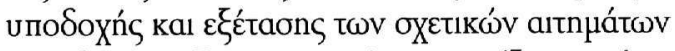

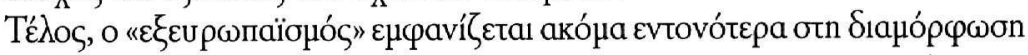

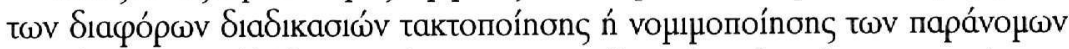

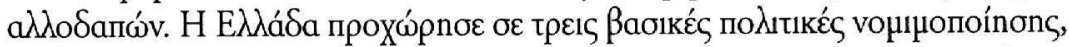

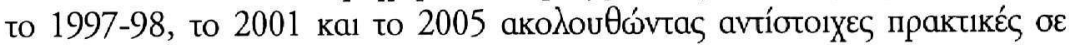

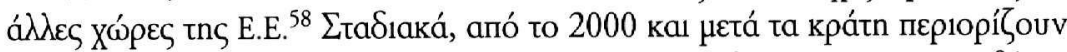

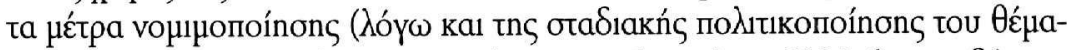

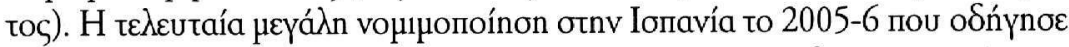

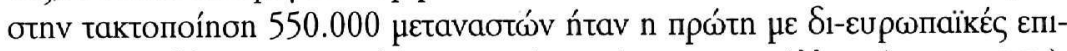

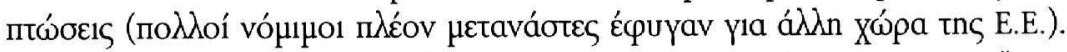

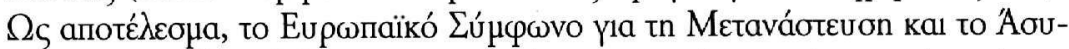

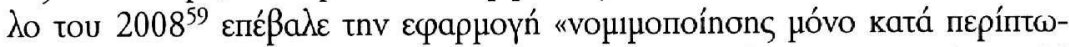

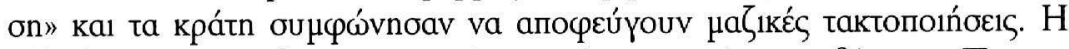

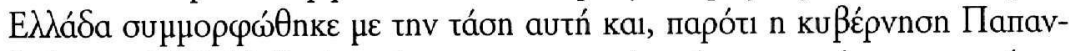

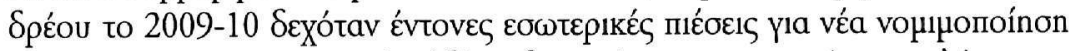

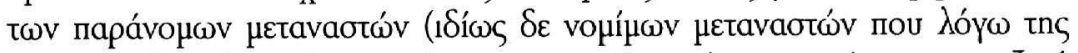

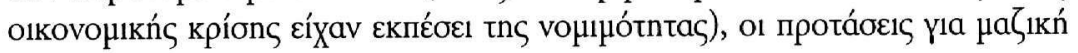

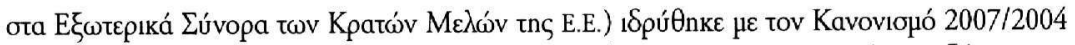

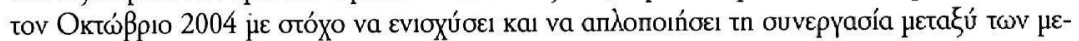

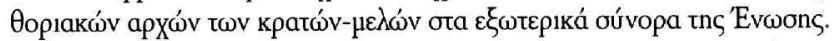

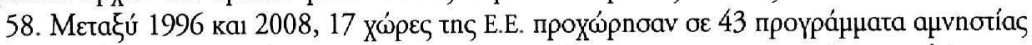

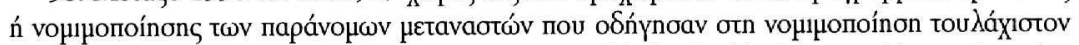

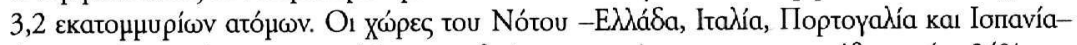

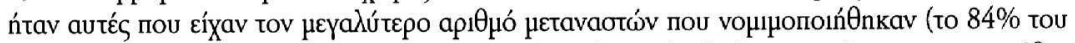

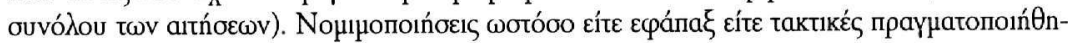

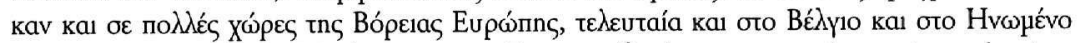

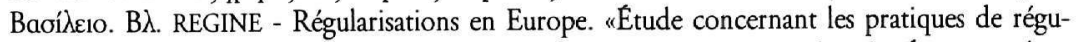
larisation des ressortissants de pays tiers en séjour irrégulier en vigueur dans les États membres de l'Union européenne», Centre International de Développement des Politiques Migratoires (ICMPD), $\Delta \varepsilon \kappa \varepsilon \dot{\mu} \mu$ Pp Publications/FR_REGINE_Summary_Final.pdf.

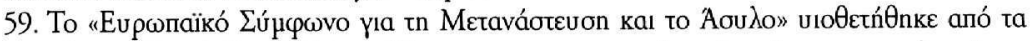

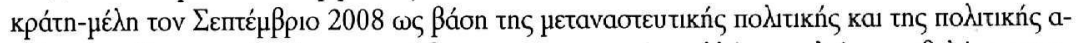

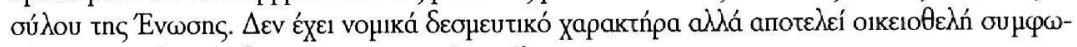

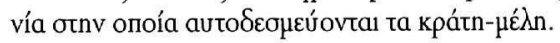




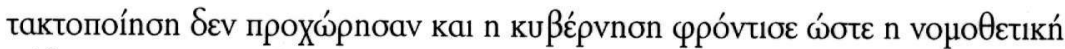

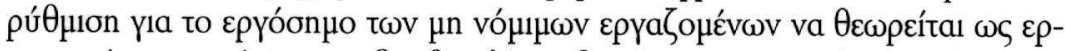

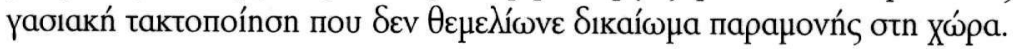

\section{7. ГYMПЕРАГМАТА}

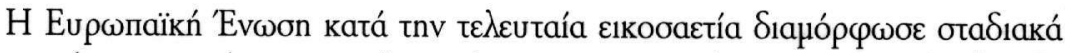

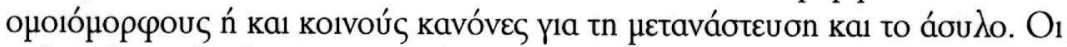

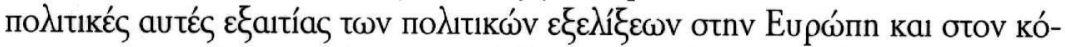

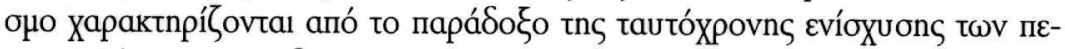

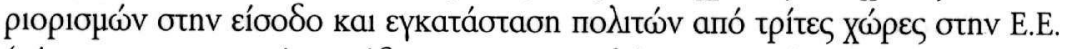

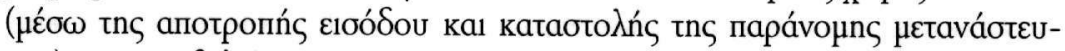

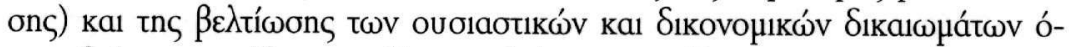

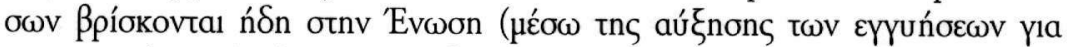

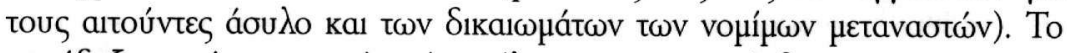

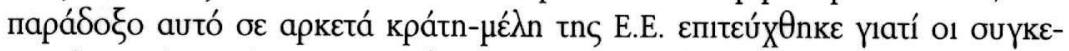

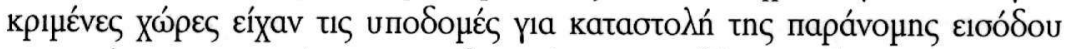

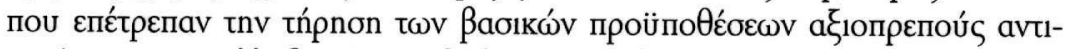

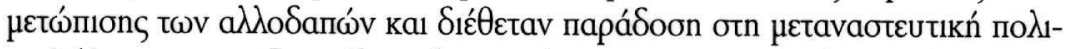

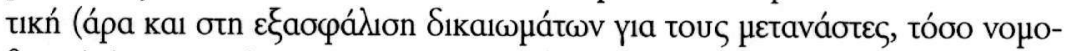

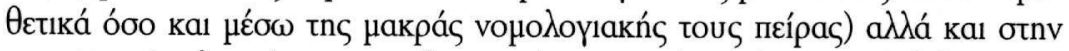

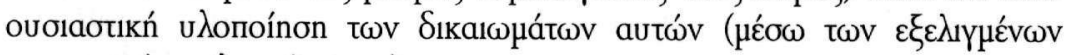

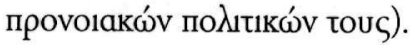

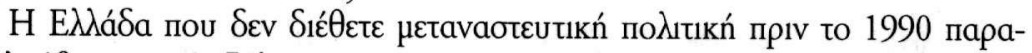

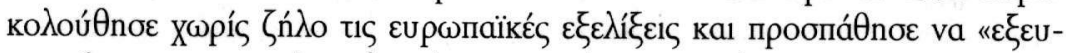

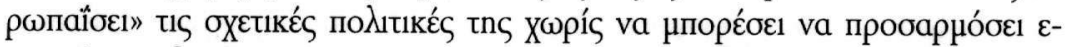

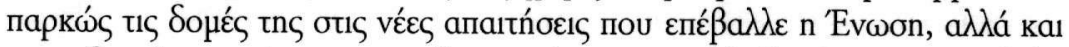

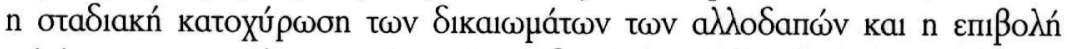

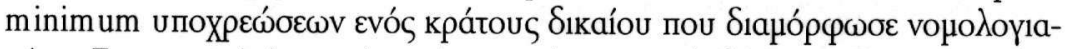

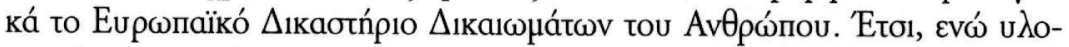

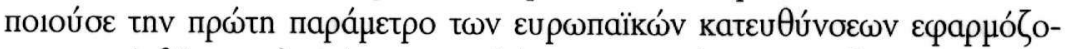

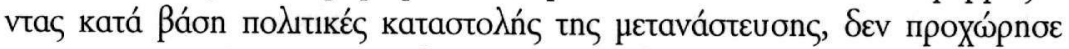

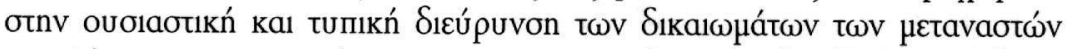

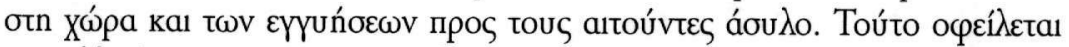

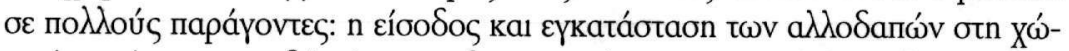

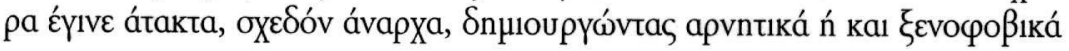




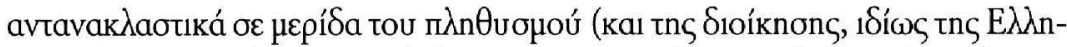

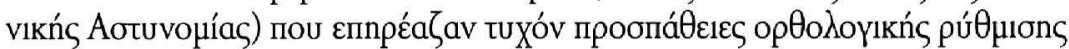

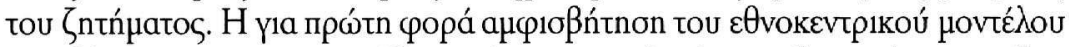

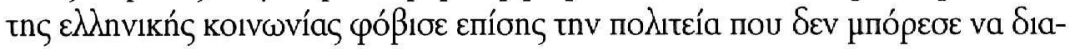

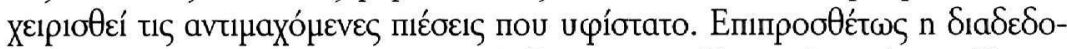

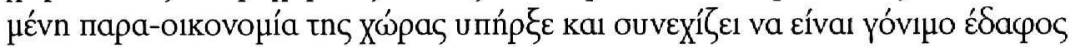

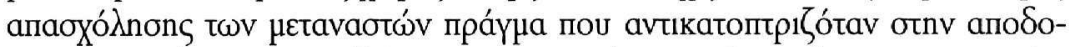

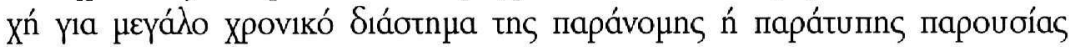

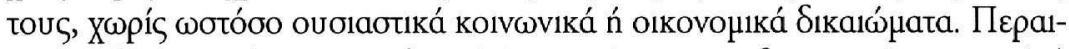

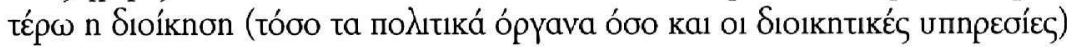

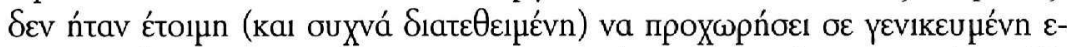

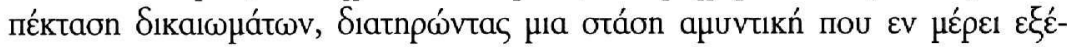

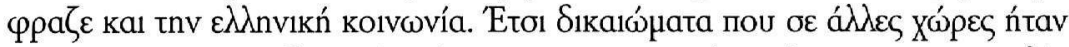

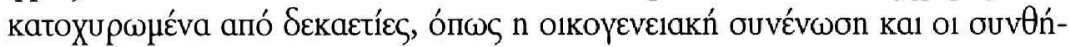

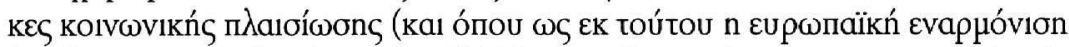

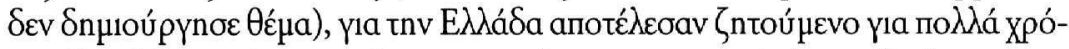

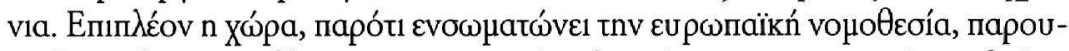

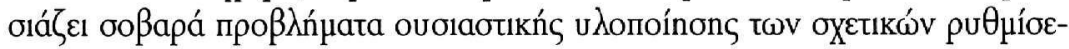

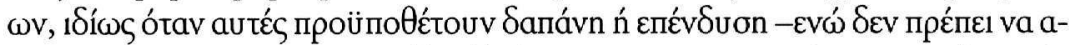

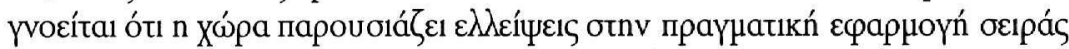

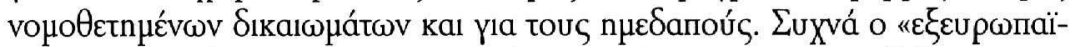

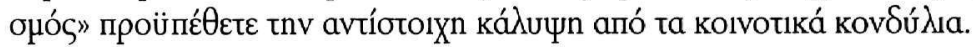

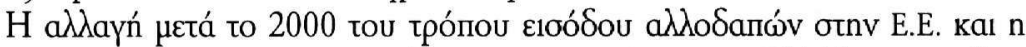

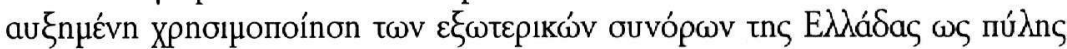

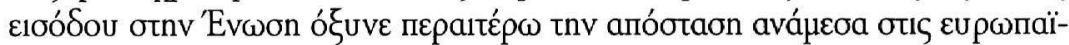

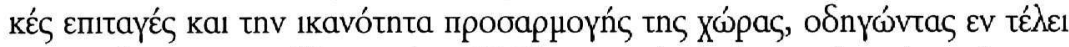

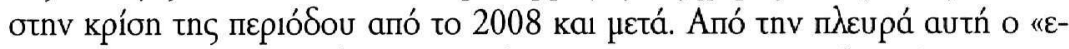

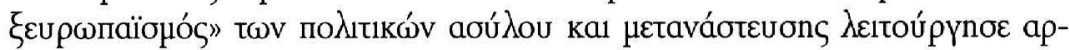

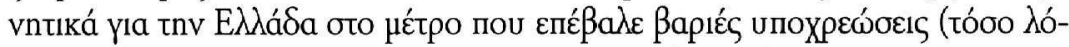

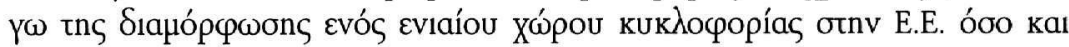

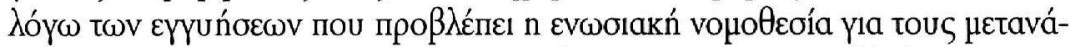

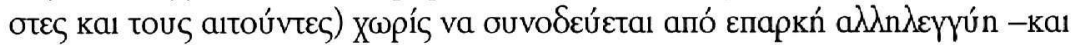

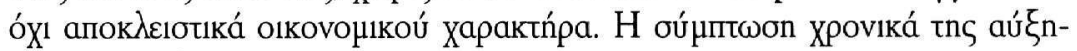

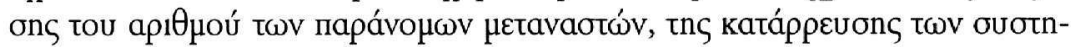

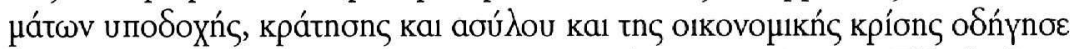

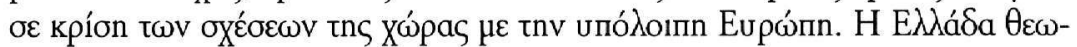

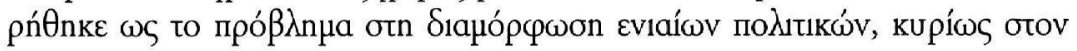




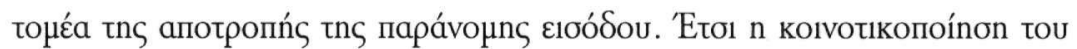

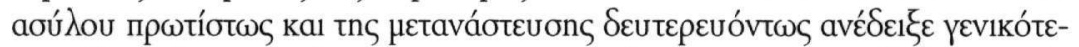

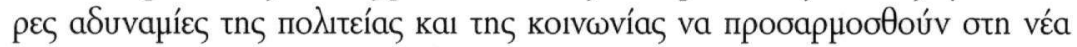

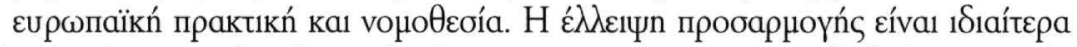

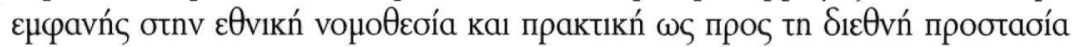

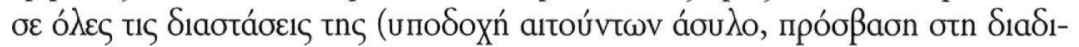

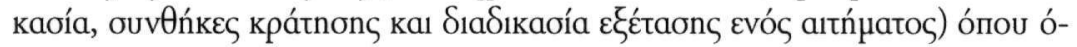

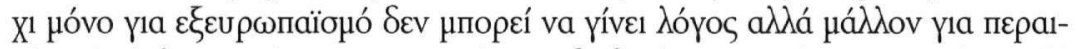

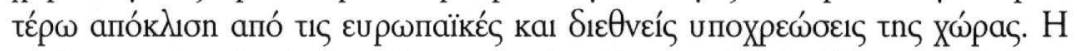

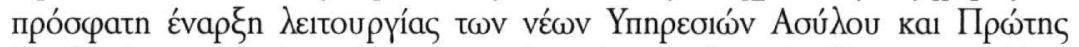

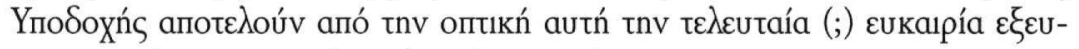

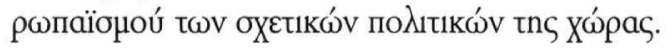

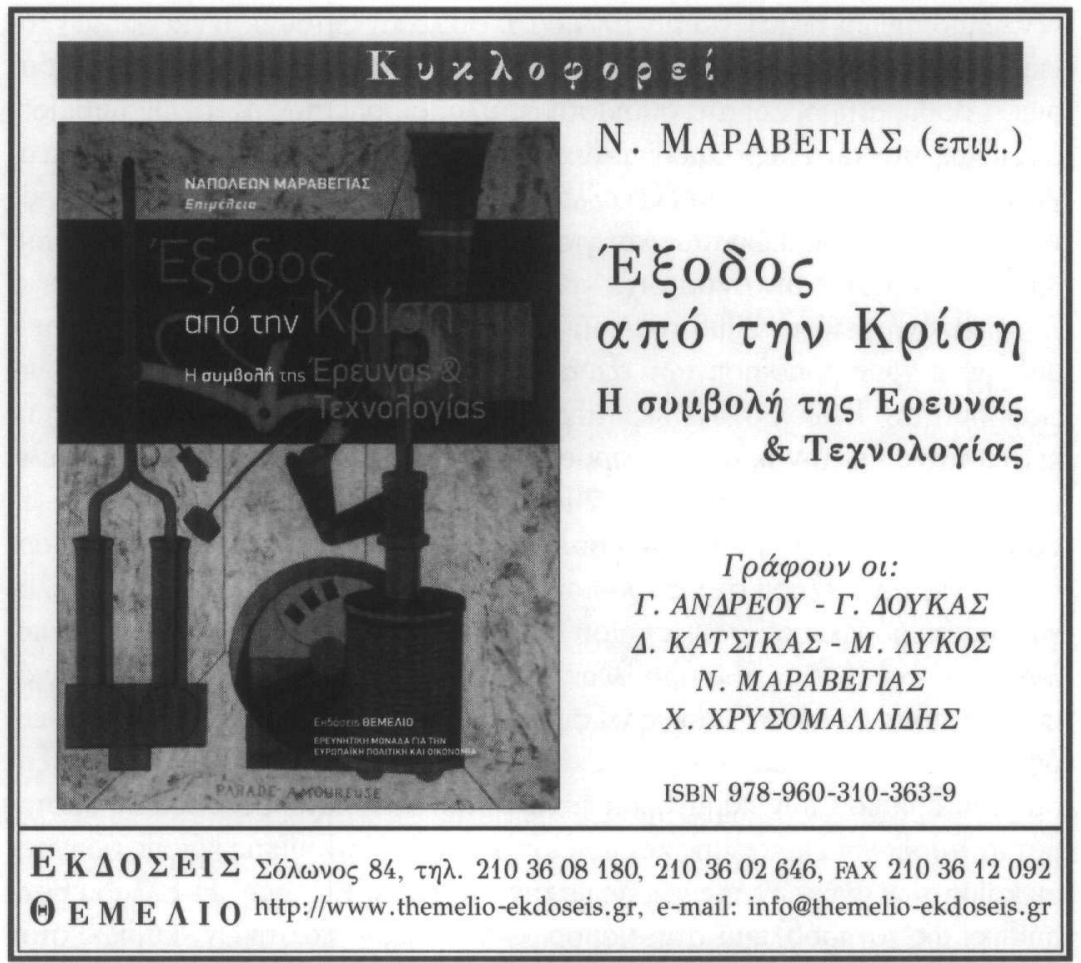

